\title{
Trade Liberalization and the Evolution of Skill Earnings Differentials in Brazil*
}

\author{
Gustavo Gonzaga Naércio Menezes Filho Cristina Terra \\ PUC-Rio USP EPGE-FGV
}

JEL classification: F13, J31

Keywords: Earnings inequality, trade liberalization

September 27, 2002

\begin{abstract}
From 1988 to 1995 , when trade liberalization was implemented in Brazil, relative earnings of skilled workers decreased. In this paper, we investigate the role of trade liberalization in explaining these relative earnings movements, by checking all the steps predicted by the HeckscherOhlin-style trade transmission mechanism. We find that: i) employment shifted from skilled to unskilled intensive sectors, and each sector increased its relative share of skilled labor; ii) relative prices fell in skill intensive sectors; iii) tariff changes across sectors were not related to skill intensities, but the pass-through from tariffs to prices was stronger in skill intensive sectors; iv) the decline in skilled earnings differentials mandated by the price variation predicted by trade is very close to the observed one. The results are compatible with trade liberalization, accounting for the observed relative earnings changes in Brazil.
\end{abstract}

\section{Introduction}

In terms of income distribution, Brazil is one of the most unequal countries in the world. In the Human Development Report (United Nations Development Program, 2000), for example, Brazil tops the ranking of income concentration

- The authors are grateful to Honório Kume for providing tariff data: Maurício Mesquita Morcira for help with price data: IBRE-FGV for providing domestic price data: Jorge Arbache, Carlos A. Cinquetti, Marc Mucndler. Raymond Robertson. and participants at seminars in CEDEPLAR, EEA, EPGE, LACEA, LAMES, PUC-Rio, UNB, and LSP for useful comments and suggestions; and Andrea Curi and Rogério Mazali for able research assistance. We thank CNPq for financial support. Terra is also sponsored by PRONEX. 
for 86 countries in the world. The ratio between the mean income appropriated by the richest $20 \%$ of families and by the poorest $20 \%$ is about 33 in Brazil, compared, for example, to 8 in the U.S., 9 in the U.K., 14 in Russia, 4 in Sri Lanka and Nepal, 18 in Kenya and 30 in Guatemala (the country with the second highest ratio). Squire and Zou (1998) also present data on Gini coefficients for several countries, which show Brazil on the top of the list with an average (over time) coefficient of 0.578 relative to a sample mean (s.d.) of $0.362(0.092)$.

The level and dispersion of wages in a country at a point in time in general depend on the distribution of its workers' characteristics, such as education, effort, experience, other observed and unobserved skills, and on the returns to these attributes. These returns, in turn, depend on the demand distribution for these characteristics. Institutional factors, such as trade unions and minimum wages, may also affect the wage structure. In Brazil, as well as in other less developed countries, education is often seen as the main source of inequality. Barros et al (2000), for example, show that the distribution of education and its returns account for about half of the wage inequality from observed sources in Brazil. This occurs because education is very unequally distributed and because returns to education are quite high in Brazil. ${ }^{1}$

Although income inequality has not changed much over the past fifteen years, education earnings differentials fell during the trade liberalization period. Brazil carried out a massive trade liberalization from 1988 to 1995 . Non-tariff barriers were first gradually substituted by tariffs, and then tariffs were reduced from an average of $39.6 \%$ in 1988 to $13.1 \%$ in 1995 . Earnings of workers with at least high school diplomas were 3.85 times higher than those for less educated workers in 1988, and this ratio decreased to 3.28 in 1995.

This paper investigates the role of trade liberalization in explaining these

\footnotetext{
'Menezes-Filho et al. (2001) compare 17 countries from Latin America and the Caribbean to find that returns to education are highest in Brazil. Lam and Levinson (1987) find that returns to education are much higher in Brazil than in the U.S.
} 
relative earnings movements, through a Heckscher-Ohlin-style mechanism. This is accomplished by performing several independent empirical exercises, including consistency checks on the causality path predicted by trade theory, using disaggregated data on tariffs, prices, wages, employment and skill intensity from 1988 to 1995 . We produce evidence showing that trade liberalization played a major role in accounting for the reduction of education earnings differentials in Brazil between 1988 and 1995.

Brazil is particularly well suited for studying the effects of trade on earnings inequality. First, Brazil moved from being a very protected economy to an open one in a relatively short period of time. Second, relative prices have displayed substantial variation over this period, mostly due to very high inflation rates (the average monthly inflation rate for the $1988-95$ period was $20,7 \%$ ). This is important because Stolper-Samuelson effects work through relative prices changes. Finally, Brazil has very high-quality and relatively unexplored establishment and household data sets.

There is a wide empirical literature studying the contribution of international trade to the rising skill premium in the U.S. and U.K., given the considerable increase in trade over the past decades. Most of this literature is based on the Heckscher-Ohlin model (see, for example, Lawrence and Slaughter, 1993, and Leamer, 1996)), but a competing view attempts to associate the rising skill premium to skill biased technological changes (see, for example, Berman, Bound and Griliches, 1994, and Katz and Autor, 1999). Although some papers have been successful in relating relative product prices changes to relative wages, most of the available evidence favors the skill biased technological change explanation (see Slaughter, 1998, for a survey of product-price studies using U.S. data).

With respect to less developed countries, the literature is far scantier (see Slaughter, 2000, for a survey on the effects of trade liberalization on labor markets in developing countries). Studies on Mexico and Chile show that these 
countries have also experienced increases in wage differentials, despite having opened their economies to trade. Hanson and Harrison (1999) argue that trade protection was skewed towards low-skilled workers in Mexico prior to the reform, so that the tariffs decline was deeper in those sectors, which could have led to the increase in wage differentials observed in this country. However, the authors did not find any correlation between price changes and skill intensity. Robertson (2001) shows that, following Mexico's entrance to the GATT, the relative price of skill-intensive goods rose and so did the relative wages of skilled workers. However, following the creation of NAFTA, the opposite took place. Beyer et al.(1999) find that a fall in the relative price of labor intensive goods in Chile helps to explain the simultaneous rise in wage inequality. This led Berman et al (1998) to argue that skill biased technological change was pervasive in developing countries as well.

All studies on developing countries identify an increase in earnings inequality. This contrasts with the evidence for Brazil, where a decrease in earnings differentials was observed. Moreover, there are no studies exploring the StolperSamuelson effects of trade on skilled earnings differentials through relative prices in Brazil (see Arbache, 2001, for a survey on the effects of trade liberalization on the Brazilian labor market).

A possible problem with the studies for other developing countries is the use of the share of non-production workers as a proxy for skill intensity. As we argue in Section 2, we consider education attainment a more adequate measure of skill. Krueger (1997) uses both education and non-production share measures of skill intensity for U.S. data, where both measures are available, and obtains qualitatively the same results. Slaughter (1998) shows that the results of studies that use either measure are comparable. This paper shows that this is not the case for Brazil. When education attainment is used to measure skill intensity, we find a reduction in earnings inequality, while a slight increase is observed 
for the nonproduction measure. We show that both movements are compatible with traditional trade theory. This should be taken as a warning for how to interpret the results of studies for other developing countries.

The paper is organized as follows. Section 2 presents the data and some stylized facts. The Brazilian trade liberalization process is briefly described in Section 3. Section 4 presents the various empirical exercises linking trade liberalization to earnings differentials and Section 5 concludes.

\section{Data and Stylized Facts}

We put together data from several different sources. For the education and earnings data we use a particularly rich data set, consisting of repeated crosssections of an annual household survey (Pesquisa Nacional de Amostras por Domicilio - PNAD), conducted each September by the Brazilian Census Bureau (IBGE) and used in several studies about the Brazilian labor market (see Lam and Shoeni, 1989, for example). Each cross-section is a representative sample of the Brazilian population and contains about 100,000 observations on households, from which around 330,000 individuals are interviewed.

From the original data, we kept only individuals with positive hours worked in the reference week and with positive monetary remuneration. The main variable used in this analysis is real hourly earnings, defined as the normal labor income in the main job in the reference month, normalized by normal weekly working hours. The sample also includes self-employed and workers with informal contracts. We measure education by completed years of formal schooling.

We split individuals into two education groups: the skilled (those that have at least completed high school, that is, 11 years of education) and the unskilled (those with less than complete high school education). As we show below, less 


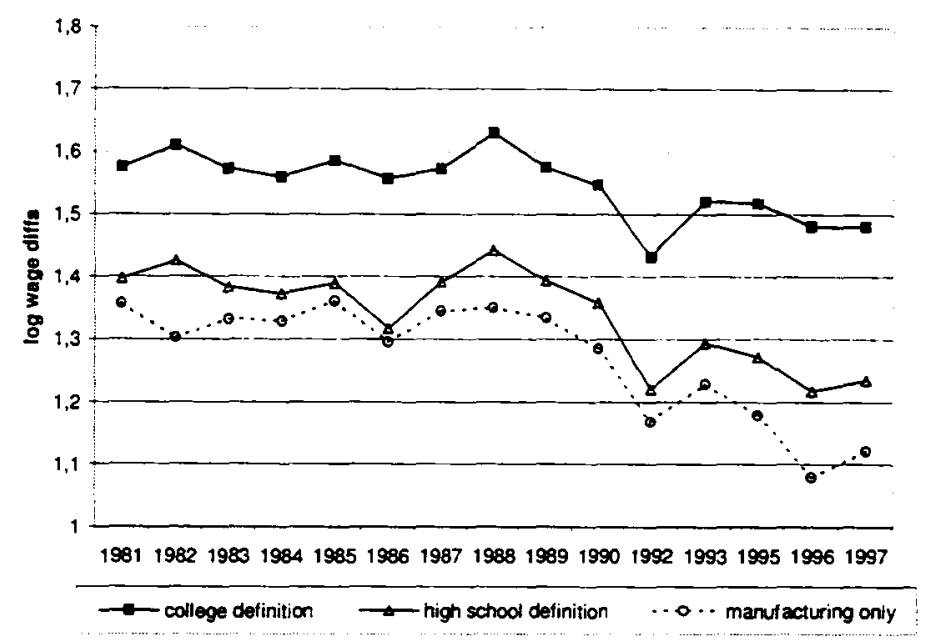

Figure 1: Education Earnings Differentials

than $10 \%$ of the workforce had completed college education over the period studied, which is clearly too small a fraction of the labor force, compared with more than $20 \%$ of workers with complete high school. Therefore, we choose to use the high school definition in all empirical exercises that follow.

Figure 1 shows the evolution of earnings differentials between skilled and unskilled workers in Brazil between 1981 and 1997. The dotted line uses our preferred measure of skill (high school or more) and refers to the manufacturing sector only. It shows that wage differentials remained basically constant between 1981 and 1988, dropping continuously afterwards. It is important to note that trade liberalization started in 1988. The continuous line with triangles shows that the behavior for the economy as a whole followed a similar path, which is to be expected, as workers can move between sectors. Finally, the line with squares shows what happens if we use college education to define a skilled worker. The drop in earnings differentials can still be noted in this case, but it is smaller in 
magnitude and concentrated in the 1988-1992 period ${ }^{2}$.

As we mentioned in the introduction, all studies that investigated the effects of trade liberalization in developing countries used the share of non-production workers as a proxy for skill intensity. In order to compare our results with those using this alternative definition, we used data on occupation from the Brazilian Industrial Surveys (Pesquisa Industrial Anual-PIA), also collected by the Brazilian Census Bureau over the same time period, and matched them to the education definitions described above. As the sectors in the industrial surveys are defined at a more disaggregated level than in the household surveys, we would obtain efficiency gains by using the non-production definition of skill if the results using the two definitions of skill were compatible.

Figures 2 and 3 show that, while there is a strong association between the high education and the non-production employment share across the manufacturing sectors, the correlation between the skill earnings differentials computed using the two definitions is much weaker. More importantly, Figure 4 shows that the earnings differentials computed using non-production occupation as a proxy for skill actually rose slightly along the sample period. This behavior contrasts with the fall of relative earnings observed when education attainment is used as a proxy for skill. Obviously, neither measure perfectly reflects skill intensity, which is unobservable to the econometrician. Education attainment fails to reflect skill intensity when, for instance, a highly educated worker is performing a task that does not require skill. On the other hand, some blue-collar workers can have highly skill demanding assignments. Nonetheless, we believe that education attainment is a more accurate proxy for skill. Based on these considerations, we use education to construct our skill composition measure in the empirical exercises that follow, but also report results of experiments using

\footnotetext{
${ }^{2}$ It is important to note that the wage differential between college educated and high school educated workers rose over the 1990s in Brazil. but this was outweighted in our sample by the decline in the high school-primary school wage differential.
} 


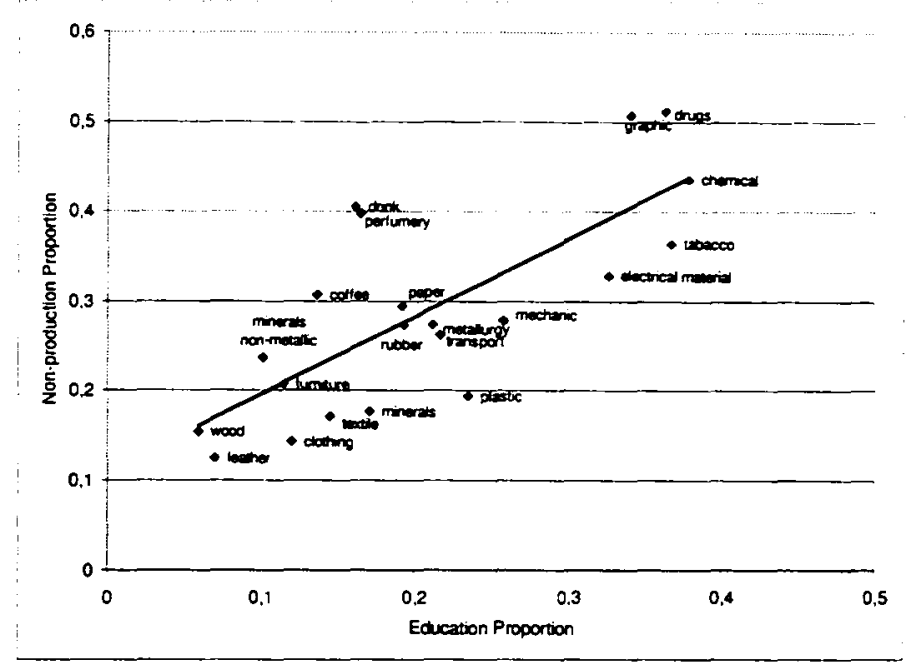

Figure 2: Education and Ocupation Employment Shares

the occupation measure.

The drop in skilled-labor relative earnings observed in Figure 1 could have been caused solely by a rise in skilled labor relative supply. Figure 5 indeed shows that there was a rise in the share of skilled workers over the same time period, both in the manufacturing sector (line with triangles) and in the economy as a whole (dotted line). The line that uses the college definition of skill (continuous with squares) also trended upwards, but at a slower pace. Note that, according to the college definition, only about $9 \%$ of the workforce was skilled in 1988-1995.

While labor supply could have a say in the decline of wage differentials observed above, it is worth noting that the relative supply of skilled workers rose steadily over the period. with minor fluctuations. By contrast, Figure 1 shows that wage differentials remained basically stable until 1988 , starting to decline at the very beginning of the trade liberalization period. This suggests 


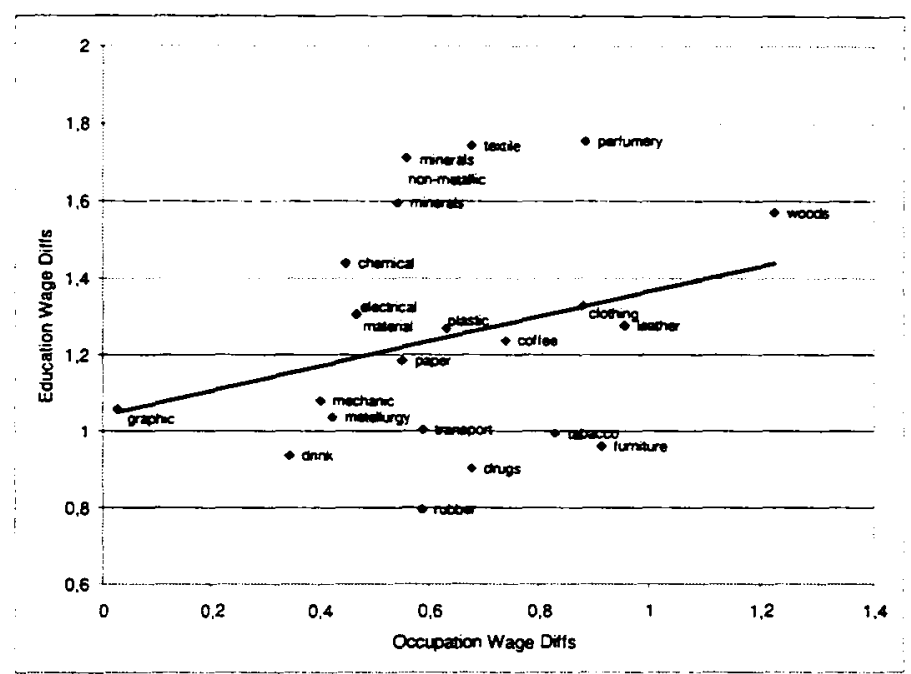

Figure 3: Education and Occupation Earnings Differentials

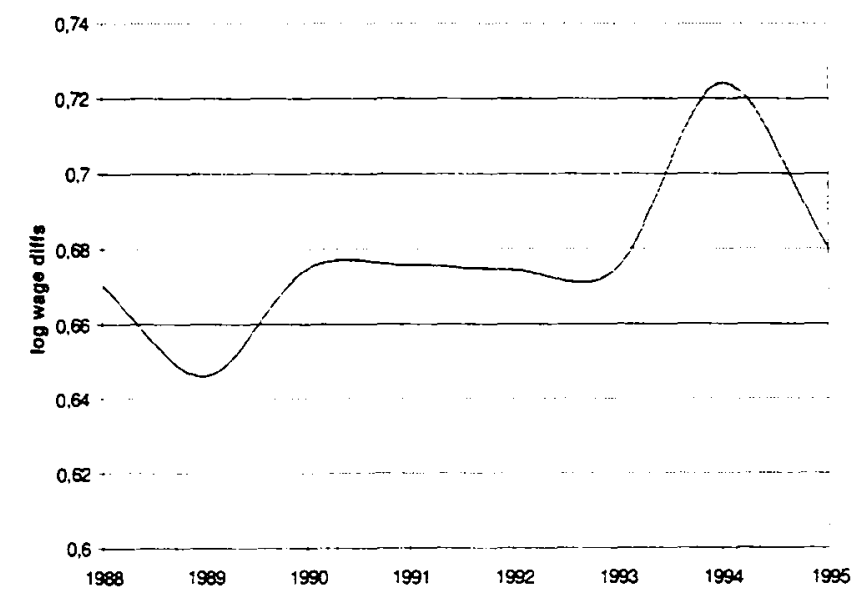

Figure 4: Occupation Earnings Differentials 


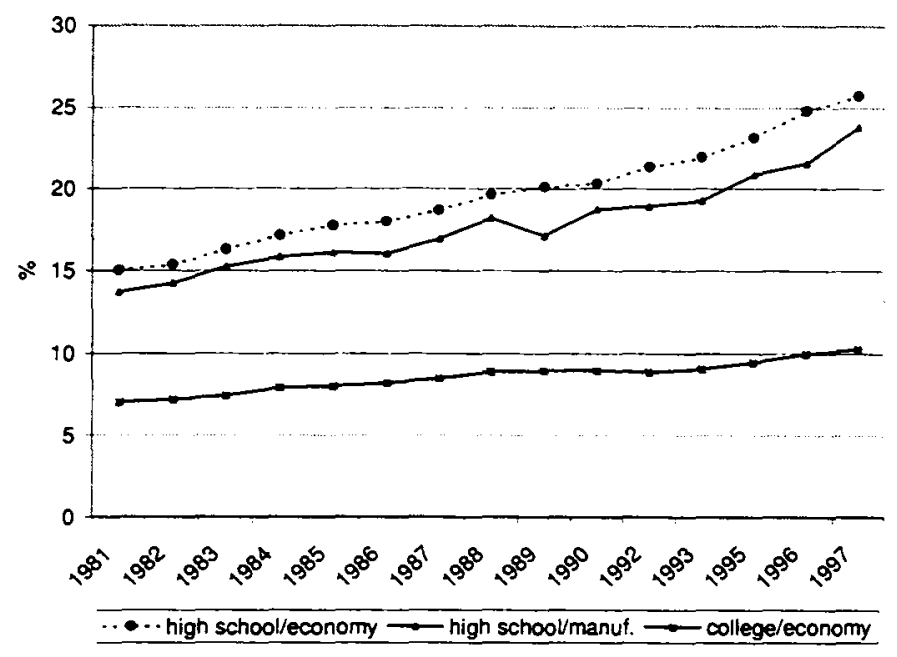

Figure 5: Education Relative Labor Supply

that other factors are behind the behavior of wage differentials. We now try to uncover these factors.

\section{Theoretical Considerations}

In traditional trade models, international trade is based on differences among countries, which may be either in their factor endowments, as in the HeckscherOhlin framework, or in the technology they possess, as in Ricardian models. A common feature in these models is that, in a small open economy, relative wages are a function only of technological parameters and relative prices. The intuition for this result is the following. In a small open economy, relative prices of tradable goods are determined abroad, and any excess supply or demand is fulfilled by trade of goods. Wages, in turn, are equal to the value of the factors' marginal productivity. As prices are exogenous, and marginal productivity depends solely on technological parameters, wages will depend only on prices 
and technological parameters, and not on factors' supply or goods' demand parameters. ${ }^{3}$

The crucial point in these models is that the effect of trade liberalization on relative wages happens through its effect on relative domestic prices. In the small country case, domestic prices are distorted by trade constraints, so that:

$$
P_{i}=\left(1+t_{i}\right)^{\alpha_{i}} E P_{i}^{*},
$$

where $P_{i}$ represents the domestic price for good $i ; t_{i}$ is the import tariff or the export subsidy (or more generally, any type of rents generated by other trade barriers, like quantitative restrictions); $E$ is the nominal exchange rate; and $P_{i}^{*}$ is the international price of good $i$. The parameter $\alpha_{i}$ captures the pass-through from tariffs to domestic prices. In a H-O world, economies' trade is completely specialized, that is, countries should import only goods in which they do not have comparative advantage. In such a world, import tariffs' pass-through to prices, $\alpha_{i}$, should be equal to one in the importing sectors and zero in the exporting ones. There is no such complete specialization in the real world, as not only $\mathrm{H}-\mathrm{O}$ forces are in play. Hence, there will be imports and exports in all sectors. However, the sector in which the country has no comparative advantage should present a higher pass-through from tariffs to prices.

Relative domestic prices are, thus, given by:

$$
\frac{P_{i}}{P_{j}}=\frac{\left(1+t_{i}\right)^{\alpha_{i}} P_{i}^{*}}{\left(1+t_{j}\right)^{\alpha_{j}} P_{j}^{*}}
$$

Equation (2) shows that a fall in trade barricrs across sectors may cause changes in relative prices. This depends on the change in relative tariffs and

\footnotetext{
${ }^{3}$ More precisely. if the economy is in the cone of diversification and the number of goods is greater or equal to the number of factors, then factor relative prices depend only on relative prices of tradable goods being produced, and technological parameters. If the cconomy is outside the diversification cone. or the number of goods is smaller than the number of factors, then relative factor prices will depend not only on technology and relative prices of goods being produced, but also on taste parameters and factor supplies. The existence of non-tradable goods does not alter the main implications of the analysis. The only effect of non-tradables is to decrease the size of the diversification cone.
} 
on the pass-through coefficients. If the pass-through is the same for all sectors, trade liberalization affects relative prices only if tariff reductions are heterogeneous across sectors. However, even a homogeneous tariffs decrease may lead to relative price changes, which happens when pass-through coefficients are different.

If falling tariffs had a larger impact on prices of sectors that use skilled labor more intensively, the new price incentives would then induce a shift of production from skill-towards non-skill-intensive sectors, increasing the demand for unskilled labor and decreasing that for skilled labor. In this case, for a given labor supply, relative skilled-labor wages would decline in order to restore labor market equilibrium.

The new relative wages, in turn, would induce producers to decrease the use of the production factor that became relatively more expensive. Hence, producers in each sector would change the mix of factors, using more skilled and less unskilled labor relative to the pre-liberalization choice. This last effect would offset the original relative demand increase for unskilled labor. In the end, one should observe higher relative wages for unskilled labor, an increase in employment and production in unskilled-intensive sectors, and an increase in the use of skilled labor in all sectors. The empirical section of this paper, Section 5 , investigates whether the comovements of sectorial variables following Brazilian trade liberalization conform to this trade transmission mechanism.

\section{Trade Liberalization in Brazil}

In this section we briefly describe the process of trade liberalization in Brazil. Brazil has a long tradition of restrictive trade policies. From World War II to 1973 the country pursued an import substitution strategy, following the trend among Latin American countries. This strategy was based on domestic mar- 
ket protection and subsidies to chosen industries. From 1960 to 1973 there was a gradual import liberalization, combined with export promotion policies, including frequent exchange rate devaluations. As a result of these policies, Brazilian exports became considerably more diversified. For example, coffee exports, which accounted for $40 \%$ of total exports in 1964, fell to only $20 \%$ in 1973. The impact on imports was not as significant. There was some import substitution in intermediate and capital goods, but imports remained highly concentrated in those goods, as well as in oil, which accounted for $20 \%$ of total imports in 1974 .

The two oil crises of the 1970s brought about large trade imbalances. The Brazilian government chose to use restrictive trade policy instead of letting exchange rate devaluations restore trade balance. Tariffs and non-tariff barriers were imposed, along with export promotion policies to compensate for the antiexport bias generated by the import restrictions. The debt crisis of the 1980 s called for large trade surpluses, which were attained by the intensification of trade restrictions and an industrial policy that gave fiscal incentives and cheap credit to selected firms.

In sum, trade barriers were built over several decades, but responding to different policy orientations. Trade policy before 1974 was designed as an incentive to selected sectors as part of the import substitution strategy. After 1974, the increase in both tariff and non-tariff barriers was a reaction to macroeconomic instability caused by the oil shocks and the debt crisis. The effect of these policies on relative prices distorted microeconomic incentives. By the end of the 1980's a maze of policy incentives was in place.

An important question for our purposes is whether the tariff structure favored skill-intensive sectors. In order to answer this question, we use data on tariffs for 60 sectors between 1988 and 1995, from Kume et al (2002). Figure 6 shows that the Brazilian tariff protection pattern in 1988 had virtually no 


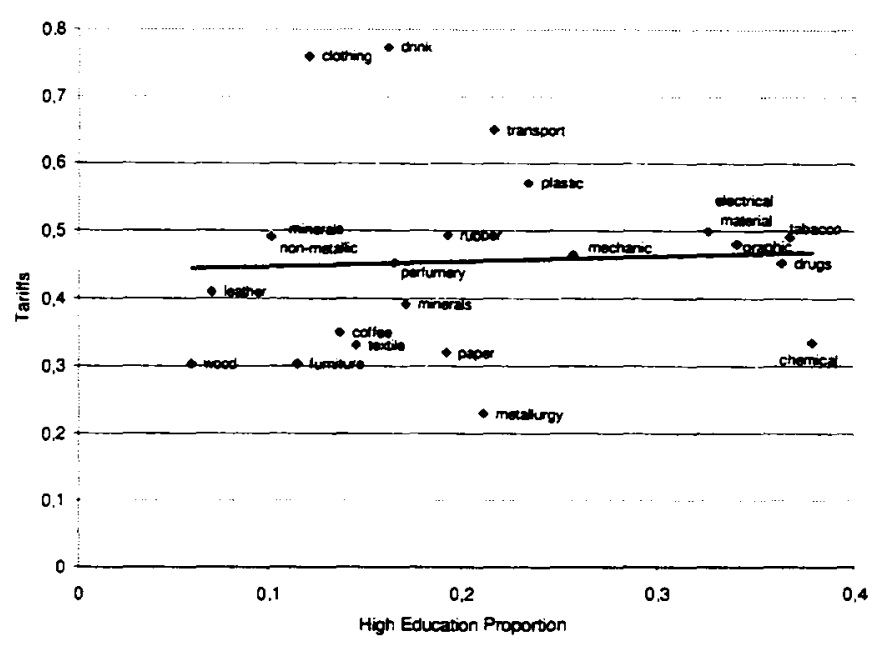

Figure 6: Tariffs and Skill Proportion

relation with skill-intensity (using education as a measure of skill). This comes as no surprise, given that trade barriers were raised to cope with macroeconomic problems, and not to protect sectors in which Brazil had no comparative advantage.

The trade liberalization process was initiated in 1988 and intensified by a new government in 1990, in conjunction with the implementation of a regional trade block, Mercosul. ${ }^{4}$ Trade liberalization was even deeper than planned. However, after the 1994 Mexican crisis, there was a partial reversal of the process. Some quantitative import restrictions were temporarily re-introduced, and some tariffs were raised. Nonetheless, the average tariff level was below $14 \%$ by November 1995. The bulk of trade liberalization occurred from 1988 to 1995 , with minor tariff changes since then. Table 1 shows the evolution of nominal and effective tariffs from 1988 to 1995 .

${ }^{4}$ The Mercosul agreement established a customs union between Brazil. Argentina, Uruguay and Paraguay. 


\begin{tabular}{ccccccccc}
\hline Nominal tariffs & 1988 & 1989 & 1990 & 1991 & 1992 & 1993 & 1994 & 1995 \\
\hline Simple average & 39.6 & 32.1 & 30.5 & 23.6 & 15.7 & 13.5 & 11.2 & 13.1 \\
Weighted average* & 37.7 & 29.4 & 27.2 & 20.9 & 14.1 & 12.5 & 10.2 & 12.2 \\
Standard deviation & 14.6 & 15.8 & 14.9 & 12.7 & 8.2 & 6.7 & 5.9 & 8.6 \\
\hline Effective tarifs & 1988 & 1989 & 1990 & 1991 & 1992 & 1993 & 1994 & 1995 \\
\hline Simple average & 52.1 & 46.5 & 47.7 & 34.8 & 20.3 & 16.7 & 13.6 & 20.1 \\
Weighted average* & 46.8 & 38.8 & 37.0 & 28.6 & 17.7 & 15.2 & 12.3 & 15.6 \\
Standard deviation & 36.6 & 44.5 & 60.6 & 36.5 & 17.2 & 13.5 & 8.4 & 37.2 \\
\hline
\end{tabular}

$\left(^{*}\right)$ Weighted by value added.

Table 1: Nominal and effective tariffs, 1988-1995

Figure 7 shows that tariffs seem to have declined slightly more in the more skill-intensive sectors, although not dramatically so, a pattern that will be further investigated below. This contrasts sharply with what was observed in Mexico. Hanson and Harrison (1999) and Robertson (2001), for example, show that Mexican tariffs were relatively lower in skill-intensive sectors before trade liberalization, and decreased less in those sectors.

\section{Empirical Results}

\subsection{Within and Between Industry Decomposition}

Our empirical exercise begins by investigating whether trade liberalization is the main reason for the drop in skill earnings differentials observed in Brazil or whether the increase in skilled labor supply alone can explain it. As discussed below, these two possible explanations have different implications for the results of standard decompositions of skilled-labor relative employment and wage bill shares into within and between industry change (see Berman, Bound and Griliches, 1994 and Autor. Katz and Krueger, 1998).

Changes in skilled-labor employment share $\left(\Delta\left(\frac{L^{s}}{L^{U}+L^{s}}\right)\right)$ may be decomposed in two parts:

$$
\Delta\left(\frac{L^{S}}{L^{U}+L^{S}}\right)=\sum_{j} s_{j} \Delta\left(\frac{L^{S}}{L^{C}+L^{S}}\right)_{j}+\sum_{j}\left(\frac{L^{S}}{L^{C}+L^{S}}\right)_{j} \Delta s_{j},
$$




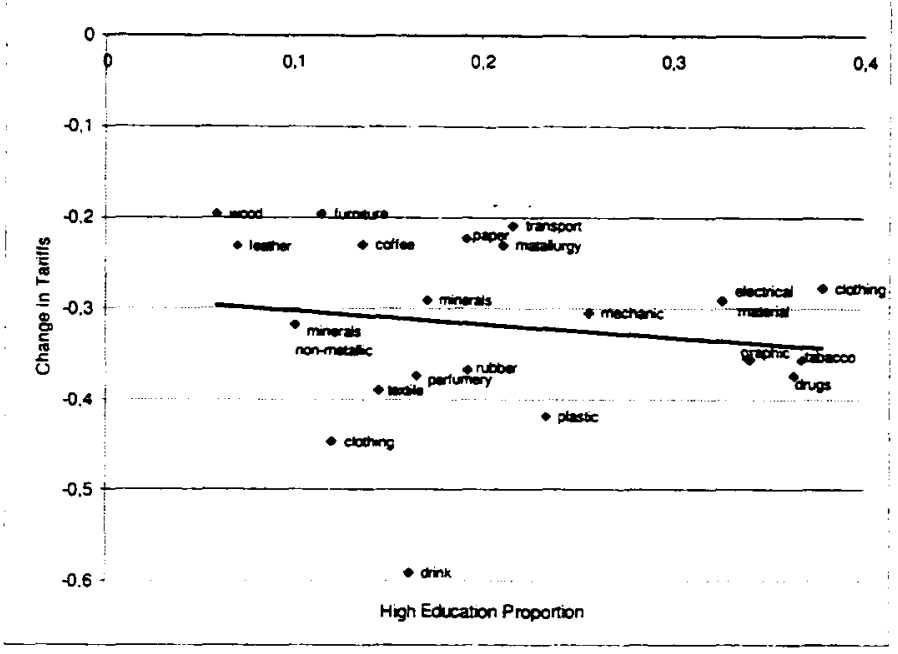

Figure 7: Changes in Tariffs and Skill Proportion

which are interpreted as:

1. within industry changes, which are changes in skilled-labor employment within each industry $\left(\Delta\left(\frac{L^{s}}{L^{U}+L^{S}}\right)\right.$, , for a given employment share in each industry $\left(s_{j}=\frac{\left(L^{U}+L^{S}\right)_{j}}{L^{U}+L^{S}}\right)$;

2. between industry changes, which are changes in each industry employment share $\left(\Delta s_{j}\right)$. for a given skilled-labor employment share in each industry $\left(\left(\frac{L^{S}}{L^{L}+L^{S}}\right)_{j}\right)$.

What would be the results of this decomposition exercise if the increase in relative labor supply were the only significant change in the economy? According to the Rybczynski theorem, for a small open economy, an increase in a factor endowment raises the output of sectors that use that factor intensively, and decreases other sectors' output, without changing the factor proportion used in each industry. In terms of equation 3 , an increase in skilled-labor supply is 
represented by a positive left hand side. Since factor proportions do not change in each industry, the first term on the right hand side, which represents the within industry effect, should be zero. The whole effect should lie in the second term - the between industry effect- which should be positive.

What would be the results of this exercise if trade were the only source behind the changes in wage inequality? As described in Section 3 , trade should have caused a decrease in relative prices of skill-intensive sectors in order to produce the observed decrease in wage inequality. On the one hand, these price incentives would decrease production in those sectors, which denote a negative between industry effect. On the other hand, the relative wage incentives would shift labor demand towards skilled workers within each industry, that is, a positive within industry effect. With given factor supplies, the two effects should offset each other. It is important to note, however, that skill biased technological change would also cause a positive within industry effect. The two effects would reinforce each other here, as opposed to the case in developed countries.

Table 2 presents the decomposition results for skilled-labor employment and wage bill shares, using education attainment as a measure of skill. Confirming the labor supply movements displayed in Figure 5, skilled-labor employment share increased $2.67 \%$ a year between 1988 and 1995 , on average. The decomposition reveals that the within effect is positive and the between effect is negative. Two important conclusions emerge: (1) labor supply changes alone cannot account for these results, and (2) the results are compatible with the trade explanation. ${ }^{5}$

Table 2 also shows that the wage bill share of skilled workers increased over

\footnotetext{
${ }^{5}$ Results not reported here. using non-production share as a proxy for skill. are also compatible with trade. But in this case. they explain the increase in earnings differentals observed for that skill measure. There was an average overall annual decrease of $0.7 \%$ in non-production employment share. This was decomposed into a negative within industry effect $(-1.4 \%)$, which outweighted a positive between industry effect $(0.7 \%)$.
} 


\begin{tabular}{cccc}
\hline & Total & Within Sectors & Between Sectors \\
\cline { 2 - 4 } High Education & 0.0267 & 0.0334 & -0.0067 \\
Employment Share & $(100 \%)$ & $(125 \%)$ & $(-25 \%)$ \\
& & & \\
High Education & 0.0084 & 0.0256 & -0.0172 \\
Wage Bill Share & $(100 \%)$ & $(304 \%)$ & $(-204 \%)$ \\
\hline
\end{tabular}

Table 2: Employment and Wage Bill Shares Decompositions, 1988-95

the period. However, it increased on average less than the employment share, $0.84 \%$ by year. This is compatible with the observed decrease in skilled labor relative wages. Consequently, the skilled worker wage bill share between sector effect is larger compared to that of employment share. The employment share decomposition presents a negative between effect, which means that, on average, employment share decreased in industries that use skilled labor more intensively. As these sectors use more of the factor that had its remuneration decreased, it is logical that their overall wage bill share should decrease by a larger proportion than the employment share.

\subsection{Consistency Checks}

In this sub-section, consistency checks examine the causality path predicted by trade theory. As discussed in Section 3, the following relationships should be investigated to determine whether trade liberalization was responsible for the decrease in skilled labor relative earnings observed in Brazil:

1. What was the pattern of relative price changes? To be consistent with the decrease in earnings inequality, one should observe a decrease in the relative prices of the sectors that use skilled labor intensively. This should be reflected in the data through a negative correlation between price changes and skill intensity.

2. Was the pattern of price changes caused by tariff changes? This can be examined through the estimation of price equations based on the rela- 
tionship established in equation (1). If the changes in relative prices in skill-intensive sectors were induced by trade liberalization, one should either observe that the largest tariff reductions occurred in the most skillintensive sectors or that the effect of tariffs on prices was larger in these sectors.

\subsubsection{Prices, Tariffs and Skill Intensity}

The first step is to check whether the pattern of price changes is consistent with the observed decrease in skilled labor relative wages. We start by estimating the following equation:

$$
\Delta \log P_{i \tau}=\beta_{0}+\beta_{1} \log \left(\frac{L^{S}}{L^{U}+L^{S}}\right)_{i, \tau-1}+\nu_{i \tau}
$$

where $P_{i \tau}$ is the wholesale price for sector $i$ in year $\tau$. The pattern of price changes must deliver a negative value for $\beta_{1}$, in order to be consistent with the decrease in skilled-labor relative earnings. Before turning to the estimated equations, Figure 8 shows that, between 1988 and 1995, prices rose less in sectors with a higher proportion of educated workers.

Equation (4) is cstimated using a panel of yearly observations from 1988 to 1995 , for a sample of 60 sectors, defined according to the Brazilian Industrial Surveys (PIA). The Brazilian wholesale price index (Índice de Preços por Atacado, IPA) was collected by the Getulio Vargas Foundation and was made compatible with the PIA sectorial definitions. We correct the standard errors of all coefficients here and in the following sub-section for the fact that our independent variable (share of educated workers) is more aggregated than the dependent variables we use.

The results of estimating equation (4), with annual data and controlling for time effects, are presented in the first three columns of Table 3. A significant negative correlation between prices and lagged skill intensity was observed, 


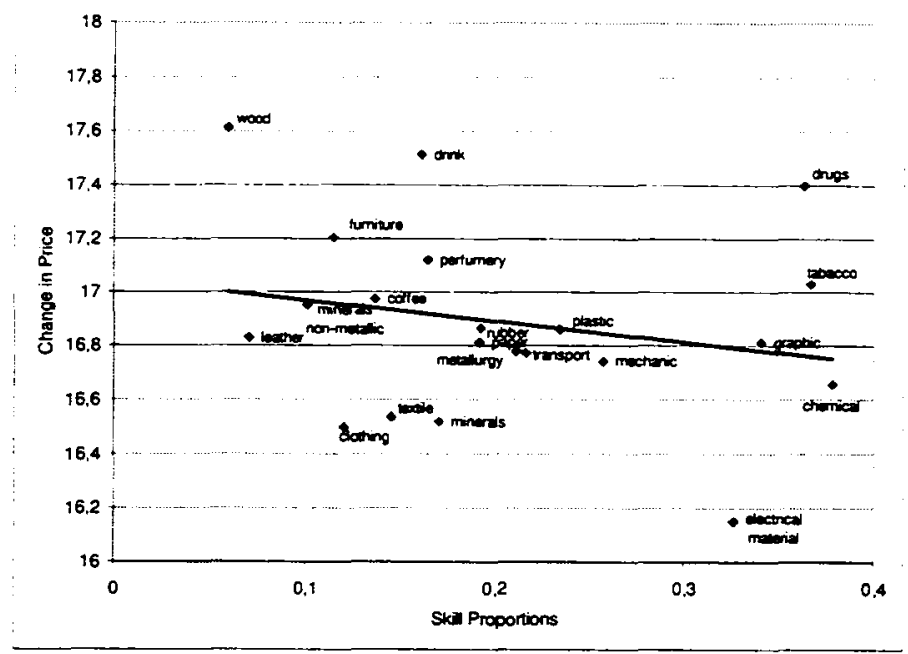

Figure 8: Price Changes and Skill Proportion

showing that relative prices changed in favor of less skill-intensive sectors. In the second column, we include the share of non-production workers as an additional control. which attracts a negative coefficient and significantly raises the estimated education share coefficient. This suggests that the two skill measures are positively correlated with each other, but relative prices moved in opposite directions with respect to them, so that the exclusion of one measure biases the coefficient of the other. In the third column, we do not use the employment weights, with no observed qualitative change in the results. Therefore, relative price changes are consistent with the observed change in earnings differentials.

According to our story, the Heckscher-Ohlin trade transmission mechanism is triggered by a reduction in trade barriers that have different impact across sectors. This could be the result of either a sharper reduction in tariffs in more skill-intensive sectors or a larger impact on prices of the tariffs reduction in these sectors. We investigate the first possibility here, while the second is examined 
in the next sub-section.

We estimate the correlation between tariff changes and skill intensity using the following equation:

$$
\Delta \log (1+t)_{i \tau}=\gamma_{0}+\gamma_{1} \log \left(\frac{L^{S}}{L^{U}+L^{S}}\right)_{i, \tau-1}+\eta_{i \tau}
$$

where $t_{i}$ stands for tariffs in sector $i$, and $\left(\frac{L^{S}}{L^{C}+L^{S}}\right)_{i}$ is the share of skilled labor employed in sector $i$.

The results are presented in columns (3) to (6) in Table 4 . Neither skill intensity measures are significantly correlated with the changes in tariffs. Therefore, as suggested by Figure 7, there is no clear pattern of tariff reductions with relation to skill intensity in Brazil.

\begin{tabular}{|c|c|c|c|c|c|c|}
\hline & \multicolumn{6}{|c|}{ Dependent Variable } \\
\hline & \multicolumn{3}{|c|}{ Change in Prices } & \multicolumn{3}{|c|}{ Change in Tariffs } \\
\hline & (1) & (2) & (3) & (4) & (5) & (6) \\
\hline Education & -0.043 & -0.070 & -0.053 & -0.002 & -0.001 & -0.001 \\
\hline Employment Share & $(0.020)$ & $(0.019)$ & $(0.021)$ & $(0.004)$ & $(0.004)$ & $(0.005)$ \\
\hline Non-production & - & 0.058 & 0.040 & - & -0.001 & 0.002 \\
\hline Employment Share & & $(0.023)$ & $(0.018)$ & & $(0.006)$ & $(0.006)$ \\
\hline Constant & 3.489 & 3.520 & 0.623 & -0.026 & -0.027 & 0.012 \\
\hline & $(0.039)$ & $(0.038)$ & $(0.035)$ & $(0.013)$ & $(0.013)$ & $(0.006)$ \\
\hline $\mathrm{N}$ & 420 & 420 & 420 & 420 & 420 & 420 \\
\hline Time Dummies & yes & yes & yes & yes & yes & yes \\
\hline Weighted Regression & yes & yes & no & yes & yes & no \\
\hline
\end{tabular}

Notes: Weights are the sector employment shares. Robust standard errors are in parentheses

Table 3: Tariffs and Skill Intensity, 1988-95

\subsubsection{Prices and tariffs}

From equation (1), domestic prices changes are related to changes in trade barriers and international prices as follows: 


$$
\Delta \log P_{i \tau}=\alpha_{i} \Delta \log \left(1+t_{i \tau}\right)+\Delta \log E+\Delta \log P_{i \tau}^{*} .
$$

Since the nominal exchange rate is the same for every sector, and data on rents generated by other trade barriers is unavailable, the equation to be estimated takes the following form:

$$
\Delta \log P_{i \tau}=\delta_{0}+\delta_{1} \alpha_{i} \Delta \log \left(1+T_{i \tau}\right)+\delta_{2} \Delta \log P_{i \tau}^{*}+\varepsilon_{i}
$$

where $T_{i}$ is the import tariff for sector $i$, and U.S. prices are used as a proxy for international prices $P_{i}^{*}$. Changes in the nominal exchange rate are a component of the constant term, $\delta_{0}$; whereas changes in the rents generated by other trade barriers are captured by the error term, $\varepsilon_{i}$. The expected values for parameters $\delta_{1}$ and $\delta_{2}$ are 1. Remember that $\alpha_{i}$ is the pass-through coefficient from tariffs to prices in sector $i$. We start by imposing that the pass-through coefficient be equal in all sectors $\left(\alpha_{i}=\alpha, \forall i\right)$, that is, we estimate the coefficient $\delta_{1} \alpha$.

Equation (7) is estimated using a panel of yearly observations from 1988 to 1995, for the same sample of 60 sectors. U.S. producer price data were drawn from the Bureau of Labor Statistics Website. We could only match 50 U.S. sectors to the equivalent Brazilian sectors.

The first column of Table 4 presents the estimation results when changes in tariffs and in U.S. prices are used as explanatory variables for price changes in Brazil. The estimated tariff coefficient is positive and significantly different from zero at conventional statistical levels. However, the coefficient for U.S. prices is not precisely estimated. This might indicate that U.S. prices are a poor proxy for international prices. Therefore, in column (2) we drop U.S. prices to gain efficiency, but the results do not change qualitatively. Finally, in the third column we use an unweighted regression and show that the results are robust to the use of weights. These results confirm that sectorial prices and tariffs moved 
together for the period as a whole.

\begin{tabular}{lccc}
\hline \multicolumn{4}{c}{ Dependent Variable: Change in Prices } \\
\hline \multirow{4}{*}{ Change in Tariffs } & 0.457 & 0.478 & 0.415 \\
& $(0.237)$ & $(0.233)$ & $(0.218)$ \\
& & & \\
Change in US Prices & 0.105 & - & - \\
& $(0.182)$ & & \\
& & & \\
Constant & 2.882 & 2.315 & 0.646 \\
N & $(0.018)$ & $(0.023)$ & $(0.015)$ \\
Time Dummies & 350 & 420 & 420 \\
Weighted Regression & yes & yes & yes \\
Notes: Robust standard errors are in parentheses. \\
Weights are the sector employment shares.
\end{tabular}

Table 4: Prices and Tariffs, 1988-95

There is one caveat in interpreting the results of this regression. Equation (1) refers to goods prices, and in the empirical estimation we use sectorial prices. The composition of goods within each sector may change over time, and this change may be correlated with changes in trade policy. On the one hand, trade liberalization may reduce or even eliminate domestic production of goods with relatively high domestic production costs. On the other hand, new products may be introduced due to the reduced cost of imported goods. Even though this is a drawback, there is nothing we can do to correct for possible measurement errors caused by it.

We now allow for a different pass-through coefficient across sectors. As discussed above, although tariff changes and skill intensity showed no significant correlation, it is still possible that relative price changes, which were consistent with the relative wages changes. were caused by trade. This would be true if sectors have different tariff pass-through coefficients. in such a way that the tariff 
reduction, albeit uniform across sectors, produced differentiated price responses. In particular, the observed relative price changes could have been caused by the trade liberalization if the pass-through coefficient from tariffs to prices were higher in skill intensive sectors.

We therefore split the sectors in two groups according to their share of educated workers: those with shares above the median in 1988 and those with shares below the median. We then interacted the changes in tariffs with these group indicators. The results are presented in Table 5. In column 1, where we include U.S. prices as an additional control, we can note that that coefficient of the change in tariffs is almost one and a half times higher in the high education sectors. This result is maintained if we drop U.S. prices, as column (2) shows. More importantly, if we do not use the employment weights in the regression, the difference in the pass-through coefficients increases substantially, to almost 5 times. We feel these results provide evidence in favor of the different tariff pass-through coefficient hypothesis.

\subsection{Mandated Wage Equations}

While the pattern of price changes is consistent with the pattern of relative earnings evolution, and seems to be determined by tariff changes, we have not as yet examined how much of the drop in skill earnings differentials could be attributed to price changes. We therefore follow another vein of the trade literature (see Baldwin and Cain, 1997, Haskel and Slaughter, 2002, and Robertson, 2001) and estimate mandated wage equations. According to the Stolper-Samuelson theorem, price changes should equal factor price changes, weighted by the factor cost share. If the only factors of production used were skilled and unskilled labor, it is easy to show that price changes could be decomposed in two terms:

$$
\Delta \log p_{j}=\frac{\theta_{j}^{S}}{\theta_{j}}\left(\Delta \log w^{S}-\Delta \log w^{U}\right)+\Delta \log w^{U},
$$




\begin{tabular}{|c|c|c|c|}
\hline \multicolumn{4}{|c|}{ Dependent Variable: Change in Prices } \\
\hline & $(1)$ & (2) & (3) \\
\hline Change in tariffs * & 0.393 & 0.402 & 0.164 \\
\hline Low Education Share Indicator & $(0.271)$ & $(0.269)$ & $(0.261)$ \\
\hline Change in tariffs $*$ & 0.591 & 0.635 & 0.783 \\
\hline High Education Share Indicator & $(0.311)$ & $(0.303)$ & $(0.265)$ \\
\hline Change in US prices & $\begin{array}{c}0.115 \\
(0.184)\end{array}$ & - & - \\
\hline Constant & $\begin{array}{c}2.882 \\
(0.018)\end{array}$ & $\begin{array}{c}2.315 \\
(0.024)\end{array}$ & $\begin{array}{c}0.646 \\
(0.015)\end{array}$ \\
\hline $\mathrm{N}$ & 350 & 420 & 420 \\
\hline Time Dummies & yes & yes & yes \\
\hline Weighted Regression & yes & yes & no \\
\hline
\end{tabular}

Notes: Weights are the sector employment shares.

Robust standard errors are in parentheses.

Table 5: Prices and Tariffs by Skill Intensity, 1988-95

where $\theta_{j}^{S}$ is the cost of skilled labor and $\theta_{j}$ is the total cost in sector $\mathrm{j}$. Therefore, regressing price changes on skilled labor cost share should yield an estimate of the economy-wide returns to skill changes.

Our estimation is based on the following regression:

$$
\Delta \log p_{j}=\phi_{0}+\phi_{1}\left(\frac{w^{S} L^{S}}{w^{U} L^{L}+w^{S} L^{S}}\right)_{j}+\eta_{j}
$$

where the estimated coefficient $\phi_{1}$ is interpreted as the changes in skill earnings differentials associated with price changes. ${ }^{6}$

Since we are interested in the effect of prices that resulted from trade liber-

${ }^{6}$ The general form for equation (8) when there are $l$ factors of production is:

$$
\Delta \log p_{j}=\frac{\theta_{j}^{1}}{\theta_{j}}\left(\Delta \log w^{1}-\Delta \log w^{2}\right)+\frac{\theta_{j}^{1}+\theta_{j}^{2}}{\theta_{j}} \Delta \log w^{2}+\sum_{k=3}^{l}\left(\frac{\theta_{j}^{k}}{\theta_{j}} \Delta \log w^{k}\right) .
$$

In this case, one could still use equation (9), but the coefficient $\phi_{1}$ should equal $\frac{\theta_{i}^{S}+\theta_{j}^{U}}{\theta_{j}}\left(\Delta \log w^{S}-\Delta \log w^{U}\right)$. which would be well estimated if the share of labor in to tal cost is time invariant. An analogous argument applies for the constant term in equation (9). 
alization, we follow Haskel and Slaughter (2002) and estimate the equation (9) in two steps. First, we estimate the change in prices predicted by the change in tariffs. For this step, we compute two alternative sets of predicted prices: those that result from the estimation of equation (7), presented in Table 4, and those that result from allowing different pass-through coefficients according to sector skill intensity, presented in Table 5 . In the second step, we estimate equation (9) using the predicted prices, instead of actual prices, as the dependent variable. In this case, the estimated coefficient $\phi_{1}$ is interpreted as the changes in returns to skill that are mandated by price changes induced by trade liberalization.

\begin{tabular}{lcc}
\hline & Dependent Variable: Change in Prices \\
\hline & $\begin{array}{c}\text { Predicted } \\
\text { by tariffs }\end{array}$ & $\begin{array}{c}\text { Predicted by tariffs, } \\
\text { diff. pass-through }\end{array}$ \\
\hline Education Cost Share & $(2)$ & $(3)$ \\
& -0.007 & -0.029 \\
& $(0.006)$ & $(0.006)$ \\
Constant & & \\
& 2.300 & 2.310 \\
& $(0.003)$ & $(0.003)$ \\
\hline Auxiliary Regression & & \\
Actual Change in Wage Diffs & -0.024 & Table $4(3)$ \\
N & 420 & -0.024 \\
Time Dummies & yes & 420 \\
\hline
\end{tabular}

Notes: Weights used in the first three columns are the sector employment shares. Robust standard errors are in parentheses.

\section{Table 6: Mandated Wages}

The results are presented in Table 6. The actual annualized fall in skill earnings differentials observed in Brazil was $2.4 \%$ on average. The first column shows that the decline in earnings differentials mandated by the price variation predicted by the change in tariffs was estimated at $0.7 \%$, but was not significantly different from zero. However, when we use the price changes predicted by tariffs, allowing for different pass-through coefficients (column 2), we find a mandated annualized skill carnings differential decline of $2.9 \%$, which is very 
close to the observed one. ${ }^{7}$ This result provides compelling evidence that trade liberalization played a major role in explaining the decrease in skilled labor relative earnings in Brazil.

\section{Conclusion}

During the trade liberalization implemented in Brazil from 1988 to 1995, earnings of workers with at least complete high school decreased with respect to earnings of less educated workers. In this paper we present evidence compatible with trade liberalization having played a role in explaining these relative earnings movements.

According to traditional trade theory, the mechanism through which trade liberalization could have caused the observed reduction in relative earnings of skilled workers in Brazil is the following. Trade liberalization should have decreased the relative prices of skill-intensive sectors, shifting production from these to unskill-intensive sectors. This should have caused a relative decrease in skilled labor demand, implying a fall in the relative wages of skilled labor . The new factor price incentives, in turn, would have induced firms in all sectors to increase the proportion of skilled labor used in production.

We perform several independent empirical exercises that check this trade transmission mechanism, using disaggregated data on tariffs, prices, wages, employment and skill intensity from 1988 to 1995 . First, a decomposition analysis of changes in skilled-labor employment share over this period reveals a positive within industry effect and a negative between industry effect. This means that employment shifted from skilled to unskilled intensive sectors, and that each sector increased its relative share of skilled labor.

Second, a panel regression of prices on skill intensities delivers a negative

\footnotetext{
${ }^{7}$ The use of non-neighted regressions. not reported here, results in a coefficient of $-5.9 \%$, with a standard error of 0.007 .
} 
coefficient, which implies that relative prices indeed fell in skill intensive sectors. Although tariff changes across sectors were not related to skill intensities, we find that the pass-through from tariffs to prices was stronger in skill intensive sectors. This is consistent with trade liberalization being responsible for the relative fall in prices of skill intensive sectors.

Finally, we apply a mandated wage equation analysis. We show that the decline in skilled earnings differentials mandated by the price variation predicted by trade is very close to the observed one. The $n$ 


\title{
Trade Liberalization and the Evolution of Skill Earnings Differentials in Brazil*
}

\author{
Gustavo Gonzaga Naércio Menezes Filho Cristina Terra \\ PUC-Rio USP EPGE-FGV \\ JEL classification: F13, J31 \\ Keywords: Earnings inequality, trade liberalization
}

September 27, 2002

\begin{abstract}
From 1988 to 1995 , when trade liberalization was implemented in Brazil, relative earnings of skilled workers decreased. In this paper, we investigate the role of trade liberalization in explaining these relative earnings movements, by checking all the steps predicted by the HeckscherOhlin-style trade transmission mechanism. We find that: i) employment shifted from skilled to unskilled intensive sectors, and each sector increased its relative share of skilled labor; ii) relative prices fell in skill intensive sectors; iii) tariff changes across sectors were not related to skill intensities, but the pass-through from tariffs to prices was stronger in skill intensive sectors; iv) the decline in skilled earnings differentials mandated by the price variation predicted by trade is very close to the observed one. The results are compatible with trade liberalization, accounting for the observed relative earnings changes in Brazil.
\end{abstract}

\section{Introduction}

In terms of income distribution, Brazil is one of the most unequal countries in the world. In the Human Development Report (United Nations Development Program, 2000), for example, Brazil tops the ranking of income concentration

\footnotetext{
- The authors are grateful to Honório Kume for providing tariff data: Maurício Mesquita Moreira for help with price data: IBRE-FGV for providing domestic price data: Jorge Arbache, Carlos A. Cinquetti, Marc Muendler, Raymond Robertson, and participants at seminars in CEDEPLAR, EEA, EPGE, LACEA. LAMES, PUC-Rio, UNB, and LSP for useful comments and suggestions; and Andrea Curi and Rogério Mazali for able research assistance. We thank CNPq for financial support. Terra is also sponsored by PRONEX.
} 
for 86 countries in the world. The ratio between the mean income appropriated by the richest $20 \%$ of families and by the poorest $20 \%$ is about 33 in Brazil, compared, for example, to 8 in the U.S., 9 in the U.K., 14 in Russia, 4 in Sri Lanka and Nepal, 18 in Kenya and 30 in Guatemala (the country with the second highest ratio). Squire and Zou (1998) also present data on Gini coefficients for several countries, which show Brazil on the top of the list with an average (over time) coefficient of 0.578 relative to a sample mean (s.d.) of $0.362(0.092)$.

The level and dispersion of wages in a country at a point in time in general depend on the distribution of its workers' characteristics, such as education, effort, experience, other observed and unobserved skills, and on the returns to these attributes. These returns, in turn, depend on the demand distribution for these characteristics. Institutional factors, such as trade unions and minimum wages, may also affect the wage structure. In Brazil, as well as in other less developed countries, education is often seen as the main source of inequality. Barros et al (2000), for example, show that the distribution of education and its returns account for about half of the wage inequality from observed sources in Brazil. This occurs because education is very unequally distributed and because returns to education are quite high in Brazil. ${ }^{1}$

Although income inequality has not changed much over the past fifteen years, education earnings differentials fell during the trade liberalization period. Brazil carried out a massive trade liberalization from 1988 to 1995. Non-tariff barriers were first gradually substituted by tariffs, and then tariffs were reduced from an average of $39.6 \%$ in 1988 to $13.1 \%$ in 1995 . Earnings of workers with at least high school diplomas were 3.85 times higher than those for less educated workers in 1988, and this ratio decreased to 3.28 in 1995.

This paper investigates the role of trade liberalization in explaining these

${ }^{1}$ Menezes-Filho et al. (2001) compare 17 countries from Latin America and the Caribbean to find that returns to education are highest in Brazil. Lam and Levinson (1987) find that returns to education are much higher in Brazil than in the C.S. 
relative earnings movements, through a Heckscher-Ohlin-style mechanism. This is accomplished by performing several independent empirical exercises, including consistency checks on the causality path predicted by trade theory, using disaggregated data on tariffs, prices, wages, employment and skill intensity from 1988 to 1995 . We produce evidence showing that trade liberalization played a major role in accounting for the reduction of education earnings differentials in Brazil between 1988 and 1995.

Brazil is particularly well suited for studying the effects of trade on earnings inequality. First, Brazil moved from being a very protected economy to an open one in a relatively short period of time. Second, relative prices have displayed substantial variation over this period, mostly due to very high inflation rates (the average monthly inflation rate for the 1988-95 period was $20,7 \%$ ). This is important because Stolper-Samuelson effects work through relative prices changes. Finally, Brazil has very high-quality and relatively unexplored establishment and household data sets.

There is a wide empirical literature studying the contribution of international trade to the rising skill premium in the U.S. and U.K., given the considerable increase in trade over the past decades. Most of this literature is based on the Heckscher-Ohlin model (see, for example, Lawrence and Slaughter, 1993, and Leamer, 1996)), but a competing view attempts to associate the rising skill premium to skill biased technological changes (see, for example, Berman, Bound and Griliches, 1994, and Katz and Autor, 1999). Although some papers have been successful in relating relative product prices changes to relative wages, most of the available evidence favors the skill biased technological change explanation (see Slaughter, 1998, for a survey of product-price studies using U.S. data).

With respect to less developed countries, the literature is far scantier (see Slaughter, 2000, for a survey on the effects of trade liberalization on labor markets in developing countries). Studies on Mexico and Chile show that these 
countries have also experienced increases in wage differentials, despite having opened their economies to trade. Hanson and Harrison (1999) argue that trade protection was skewed towards low-skilled workers in Mexico prior to the reform, so that the tariffs decline was deeper in those sectors, which could have led to the increase in wage differentials observed in this country. However, the authors did not find any correlation between price changes and skill intensity. Robertson (2001) shows that, following Mexico's entrance to the GATT, the relative price of skill-intensive goods rose and so did the relative wages of skilled workers. However, following the creation of NAFTA, the opposite took place. Beyer et al.(1999) find that a fall in the relative price of labor intensive goods in Chile helps to explain the simultaneous rise in wage inequality. This led Berman et al (1998) to argue that skill biased technological change was pervasive in developing countries as well.

All studies on developing countries identify an increase in earnings inequality. This contrasts with the evidence for Brazil, where a decrease in earnings differentials was observed. Moreover, there are no studies exploring the StolperSamuelson effects of trade on skilled earnings differentials through relative prices in Brazil (see Arbache, 2001, for a survey on the effects of trade liberalization on the Brazilian labor market).

A possible problem with the studies for other developing countries is the use of the share of non-production workers as a proxy for skill intensity. As we argue in Section 2, we consider education attainment a more adequate measure of skill. Krueger (1997) uses both education and non-production share measures of skill intensity for U.S. data, where both measures are available, and obtains qualitatively the same results. Slaughter (1998) shows that the results of studies that use either measure are comparable. This paper shows that this is not the case for Brazil. When education attainment is used to measure skill intensity, we find a reduction in earnings inequality, while a slight increase is observed 
for the nonproduction measure. We show that both movements are compatible with traditional trade theory. This should be taken as a warning for how to interpret the results of studies for other developing countries.

The paper is organized as follows. Section 2 presents the data and some stylized facts. The Brazilian trade liberalization process is briefly described in Section 3. Section 4 presents the various empirical exercises linking trade liberalization to earnings differentials and Section 5 concludes.

\section{Data and Stylized Facts}

We put together data from several different sources. For the education and earnings data we use a particularly rich data set, consisting of repeated crosssections of an annual household survey (Pesquisa Nacional de Amostras por Domicilio - PNAD), conducted each September by the Brazilian Census Bureau (IBGE) and used in several studies about the Brazilian labor market (see Lam and Shoeni, 1989, for example). Each cross-section is a representative sample of the Brazilian population and contains about 100,000 observations on households, from which around 330,000 individuals are interviewed.

From the original data, we kept only individuals with positive hours worked in the reference week and with positive monetary remuneration. The main variable used in this analysis is real hourly earnings, defined as the normal labor income in the main job in the reference month, normalized by normal weekly working hours. The sample also includes self-employed and workers with informal contracts. We measure education by completed years of formal schooling.

We split individuals into two education groups: the skilled (those that have at least completed high school, that is, 11 years of education) and the unskilled (those with less than complete high school education). As we show below, less 


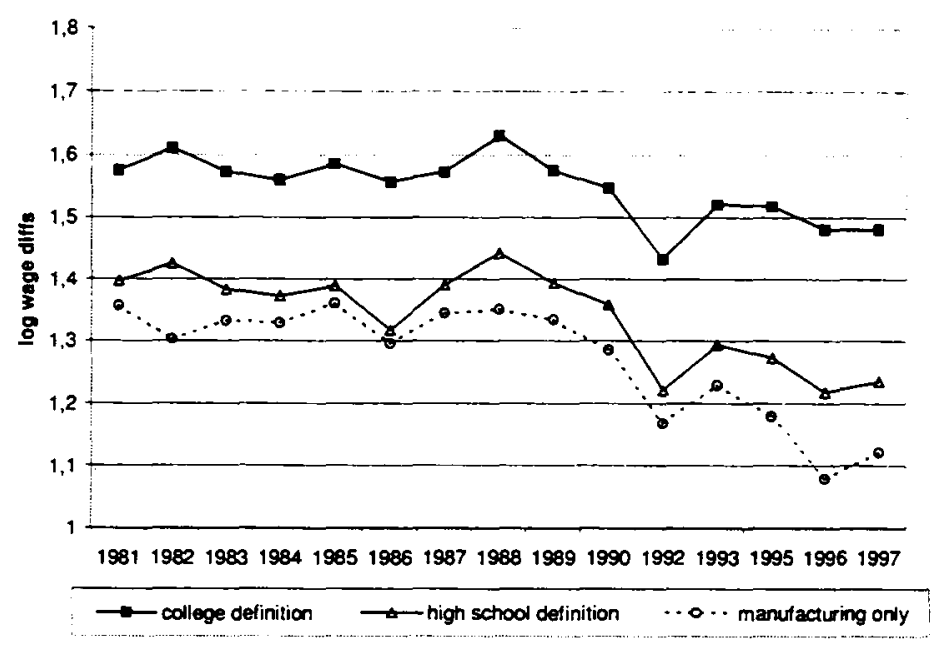

Figure 1: Education Earnings Differentials

than $10 \%$ of the workforce had completed college education over the period studied, which is clearly too small a fraction of the labor force, compared with more than $20 \%$ of workers with complete high school. Therefore, we choose to use the high school definition in all empirical exercises that follow.

Figure 1 shows the evolution of earnings differentials between skilled and unskilled workers in Brazil between 1981 and 1997. The dotted line uses our preferred measure of skill (high school or more) and refers to the manufacturing sector only. It shows that wage differentials remained basically constant between 1981 and 1988, dropping continuously afterwards. It is important to note that trade liberalization started in 1988. The continuous line with triangles shows that the behavior for the economy as a whole followed a similar path, which is to be expected, as workers can move between sectors. Finally, the line with squares shows what happens if we use college education to define a skilled worker. The drop in earnings differentials can still be noted in this case, but it is smaller in 
magnitude and concentrated in the 1988-1992 period².

As we mentioned in the introduction, all studies that investigated the effects of trade liberalization in developing countries used the share of non-production workers as a proxy for skill intensity. In order to compare our results with those using this alternative definition, we used data on occupation from the Brazilian Industrial Surveys (Pesquisa Industrial Anual-PIA), also collected by the Brazilian Census Bureau over the same time period, and matched them to the education definitions described above. As the sectors in the industrial surveys are defined at a more disaggregated level than in the household surveys, we would obtain efficiency gains by using the non-production definition of skill if the results using the two definitions of skill were compatible.

Figures 2 and 3 show that, while there is a strong association between the high education and the non-production employment share across the manufacturing sectors, the correlation between the skill earnings differentials computed using the two definitions is much weaker. More importantly, Figure 4 shows that the earnings differentials computed using non-production occupation as a proxy for skill actually rose slightly along the sample period. This behavior contrasts with the fall of relative earnings observed when education attainment is used as a proxy for skill. Obviously, neither measure perfectly reflects skill intensity, which is unobservable to the econometrician. Education attainment fails to reflect skill intensity when, for instance, a highly educated worker is performing a task that does not require skill. On the other hand, some blue-collar workers can have highly skill demanding assignments. Nonetheless, we believe that education attainment is a more accurate proxy for skill. Based on these considerations, we use education to construct our skill composition measure in the empirical exercises that follow, but also report results of experiments using

\footnotetext{
${ }^{2}$ It is important to note that the wage differential between college educated and high school educated workers rose over the $1990 \mathrm{~s}$ in Brazil, but this was outweighted in our sample by the decline in the high school-primary schuol wage differential.
} 


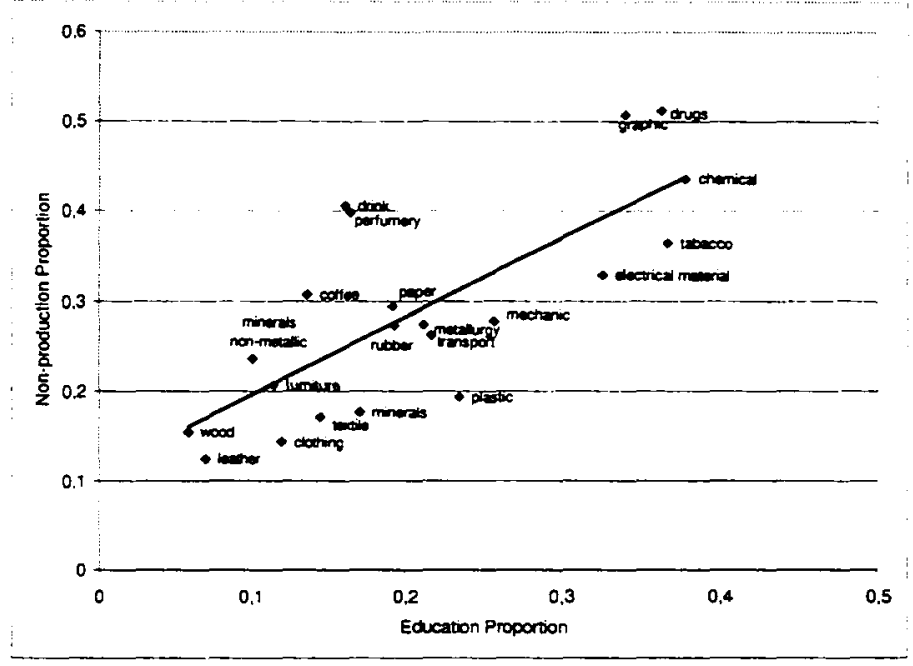

Figure 2: Education and Ocupation Employment Shares

the occupation measure.

The drop in skilled-labor relative earnings observed in Figure 1 could have been caused solely by a rise in skilled labor relative supply. Figure 5 indeed shows that there was a rise in the share of skilled workers over the same time period, both in the manufacturing sector (line with triangles) and in the economy as a whole (dotted line). The line that uses the college definition of skill (continuous with squares) also trended upwards, but at a slower pace. Note that, according to the college definition, only about $9 \%$ of the workforce was skilled in 1988-1995.

While labor supply could have a say in the decline of wage differentials observed above, it is worth noting that the relative supply of skilled workers rose steadily over the period, with minor fluctuations. By contrast, Figure 1 shows that wage differentials remained basically stable until 1988, starting to decline at the very beginning of the trade liberalization period. This suggests 


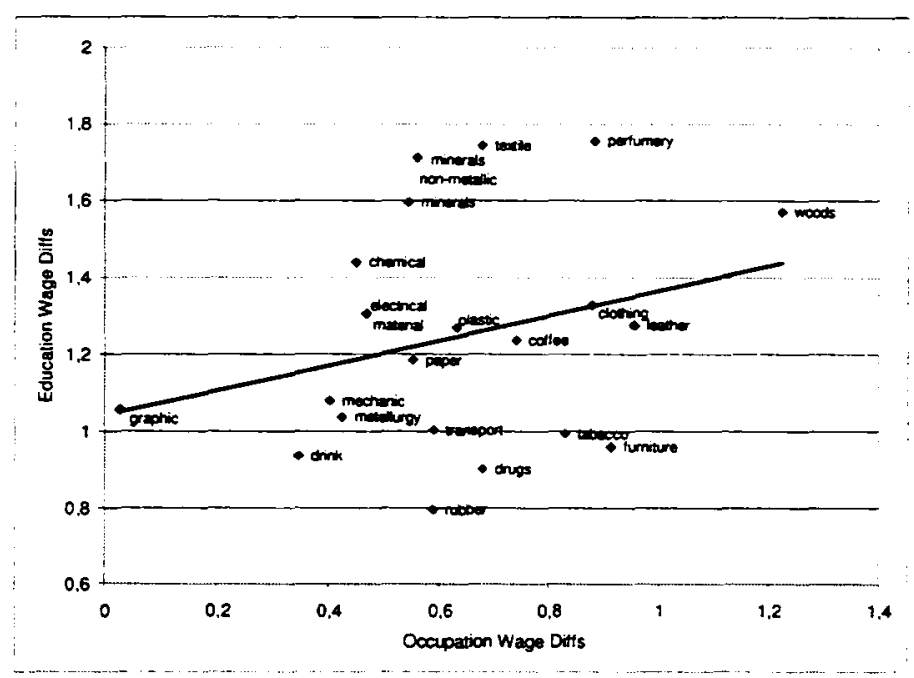

Figure 3: Education and Occupation Earnings Differentials

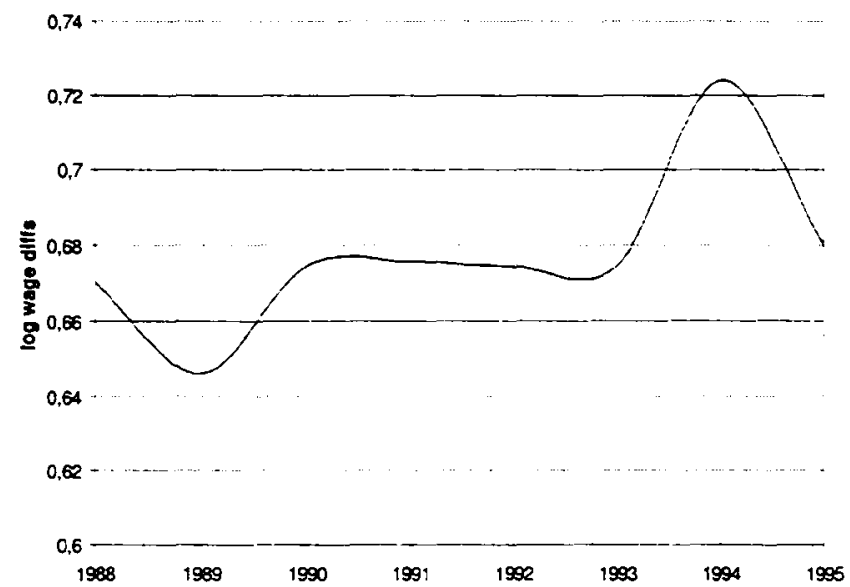

Figure 4: Occupation Earnings Differentials 


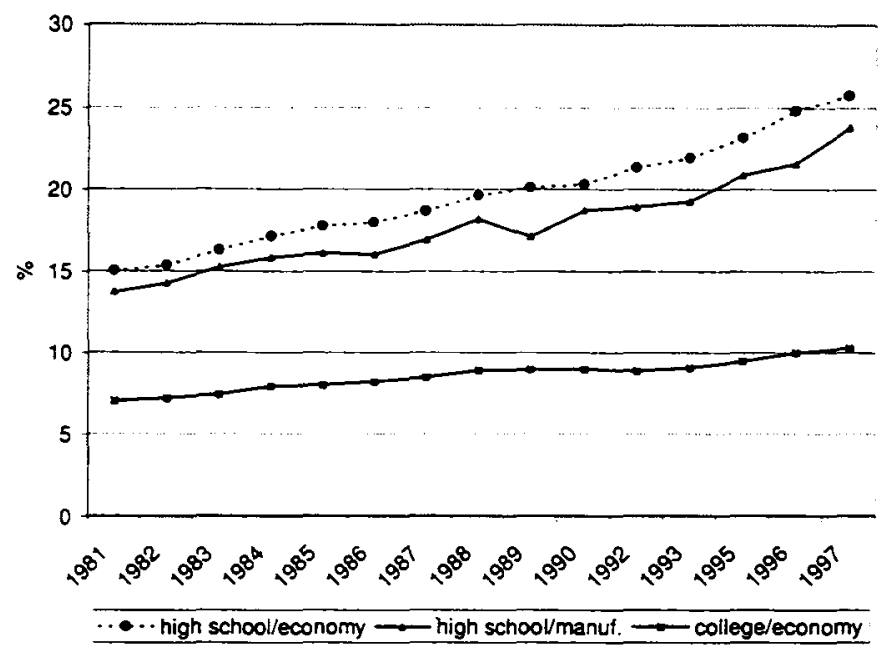

Figure 5: Education Relative Labor Supply

that other factors are behind the behavior of wage differentials. We now try to uncover these factors.

\section{Theoretical Considerations}

In traditional trade models, international trade is based on differences among countries, which may be either in their factor endowments, as in the HeckscherOhlin framework, or in the technology they possess, as in Ricardian models. A common feature in these models is that, in a small open economy, relative wages are a function only of technological parameters and relative prices. The intuition for this result is the following. In a small open economy, relative prices of tradable goods are determined abroad, and any excess supply or demand is fulfilled by trade of goods. Wages, in turn, are equal to the value of the factors' marginal productivity. As prices are exogenous, and marginal productivity depends solely on technological parameters, wages will depend only on prices 
and technological parameters, and not on factors' supply or goods' demand parameters. 3

The crucial point in these models is that the effect of trade liberalization on relative wages happens through its effect on relative domestic prices. In the small country case, domestic prices are distorted by trade constraints, so that:

$$
P_{i}=\left(1+t_{i}\right)^{\alpha_{i}} E P_{i}^{*}
$$

where $P_{i}$ represents the domestic price for good $i ; t_{i}$ is the import tariff or the export subsidy (or more generally, any type of rents generated by other trade barriers, like quantitative restrictions); $E$ is the nominal exchange rate; and $P_{i}^{*}$ is the international price of good $i$. The parameter $\alpha_{i}$ captures the pass-through from tariffs to domestic prices. In a $\mathrm{H}-\mathrm{O}$ world, economies' trade is completely specialized, that is, countries should import only goods in which they do not have comparative advantage. In such a world, import tariffs' pass-through to prices, $\alpha_{i}$, should be equal to one in the importing sectors and zero in the exporting ones. There is no such complete specialization in the real world, as not only $\mathrm{H}-\mathrm{O}$ forces are in play. Hence, there will be imports and exports in all sectors. However, the sector in which the country has no comparative advantage should present a higher pass-through from tariffs to prices.

Relative domestic prices are, thus, given by:

$$
\frac{P_{i}}{P_{j}}=\frac{\left(1+t_{i}\right)^{\alpha_{i}} P_{i}^{*}}{\left(1+t_{j}\right)^{\alpha_{j}} P_{j}^{*}}
$$

Equation (2) shows that a fall in trade barricrs across sectors may cause changes in relative prices. This depends on the change in relative tariffs and

\footnotetext{
${ }^{3}$ More precisely, if the economy is in the cone of diversification and the number of goods is greater or equal to the number of factors, then factor relative prices depend only on relative prices of tradable goods being produced, and technological parameters. If the economy is outside the diversification cone, or the number of goods is smaller than the number of factors: then relative factor prices will depend not only on technology and relative prices of goods being produced, but also on taste parameters and factor supplies. The existence of non-tradable goods does not alter the main implications of the analysis. The unly effect of non-tradables is to decrease the size of the diversification cone.
} 
on the pass-through coefficients. If the pass-through is the same for all sectors, trade liberalization affects relative prices only if tariff reductions are heterogeneous across sectors. However, even a homogeneous tariffs decrease may lead to relative price changes, which happens when pass-through coefficients are different.

If falling tariffs had a larger impact on prices of sectors that use skilled labor more intensively, the new price incentives would then induce a shift of production from skill- towards non-skill-intensive sectors, increasing the demand for unskilled labor and decreasing that for skilled labor. In this case, for a given labor supply, relative skilled-labor wages would decline in order to restore labor market equilibrium.

The new relative wages, in turn, would induce producers to decrease the use of the production factor that became relatively more expensive. Hence, producers in each sector would change the mix of factors, using more skilled and less unskilled labor relative to the pre-liberalization choice. This last effect would offset the original relative demand increase for unskilled labor. In the end, one should observe higher relative wages for unskilled labor, an increase in employment and production in unskilled-intensive sectors, and an increase in the use of skilled labor in all sectors. The empirical section of this paper, Section $\overline{5}$, investigates whether the comovements of sectorial variables following Brazilian trade liberalization conform to this trade transmission mechanism.

\section{Trade Liberalization in Brazil}

In this section we briefly describe the process of trade liberalization in Brazil. Brazil has a long tradition of restrictive trade policies. From World War II to 1973 the country pursued an import substitution strategy, following the trend among Latin American countries. This strategy was based on domestic mar- 
ket protection and subsidies to chosen industries. From 1960 to 1973 there was a gradual import liberalization, combined with export promotion policies, including frequent exchange rate devaluations. As a result of these policies, Brazilian exports became considerably more diversified. For example, coffee exports, which accounted for $40 \%$ of total exports in 1964, fell to only $20 \%$ in 1973. The impact on imports was not as significant. There was some import substitution in intermediate and capital goods, but imports remained highly concentrated in those goods, as well as in oil, which accounted for $20 \%$ of total imports in 1974

The two oil crises of the 1970s brought about large trade imbalances. The Brazilian government chose to use restrictive trade policy instead of letting exchange rate devaluations restore trade balance. Tariffs and non-tariff barriers were imposed, along with export promotion policies to compensate for the antiexport bias generated by the import restrictions. The debt crisis of the 1980 s called for large trade surpluses, which were attained by the intensification of trade restrictions and an industrial policy that gave fiscal incentives and cheap credit to selected firms.

In sum, trade barriers were built over several decades, but responding to different policy orientations. Trade policy before 1974 was designed as an incentive to selected sectors as part of the import substitution strategy. After 1974, the increase in both tariff and non-tariff barriers was a reaction to macroeconomic instability caused by the oil shocks and the debt crisis. The effect of these policies on relative prices distorted microeconomic incentives. By the end of the 1980's a maze of policy incentives was in place.

An important question for our purposes is whether the tariff structure favored skill-intensive sectors. In order to answer this question, we use data on tariffs for 60 sectors between 1988 and 1995, from Kume et al (2002). Figure 6 shows that the Brazilian tariff protection pattern in 1988 had virtually no 


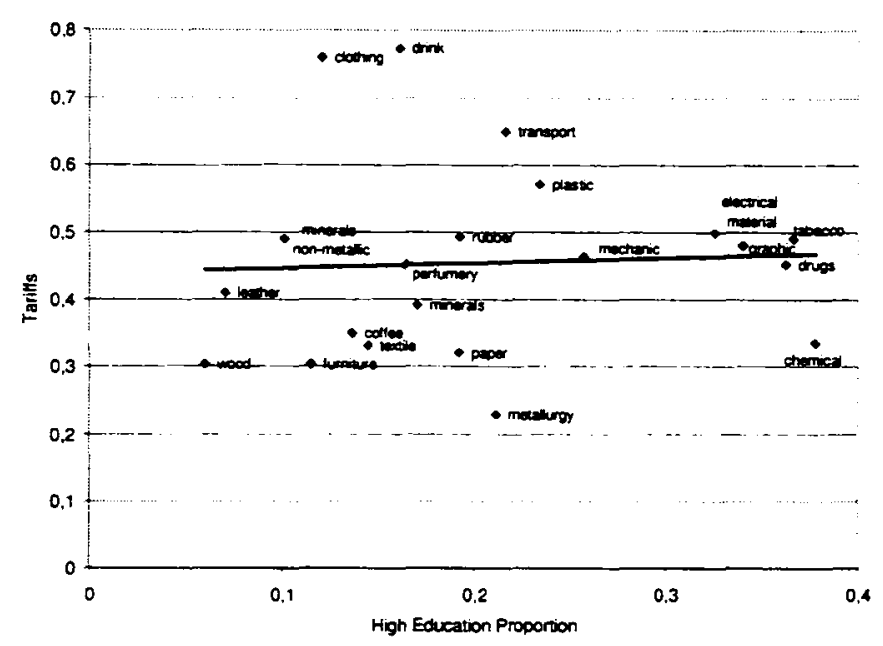

Figure 6: Tariffs and Skill Proportion

relation with skill-intensity (using education as a measure of skill). This comes as no surprise, given that trade barriers were rajsed to cope with macroeconomic problems, and not to protect sectors in which Brazil had no comparative advantage.

The trade liberalization process was initiated in 1988 and intensified by a new government in 1990, in conjunction with the implementation of a regional trade block, Mercosul. ${ }^{4}$ Trade liberalization was even deeper than planned. However, after the 1994 Mexican crisis, there was a partial reversal of the process. Some quantitative import restrictions were temporarily re-introduced, and some tariffs were raised. Nonetheless, the average tariff level was below $14 \%$ by November 1995. The bulk of trade liberalization occurred from 1988 to 1995 , with minor tariff changes since then. Table 1 shows the evolution of nominal and effective tariffs from 1988 to 1995 .

\footnotetext{
${ }^{4}$ The Mercosul agreement established a customs union between Brazil. Argentina, Uruguay and Paraguay.
} 


\begin{tabular}{ccccccccc}
\hline Nominal tariffs & 1988 & 1989 & 1990 & 1991 & 1992 & 1993 & 1994 & 1995 \\
\hline Simple average & 39.6 & 32.1 & 30.5 & 23.6 & 15.7 & 13.5 & 11.2 & 13.1 \\
Weighted average* & 37.7 & 29.4 & 27.2 & 20.9 & 14.1 & 12.5 & 10.2 & 12.2 \\
Standard deviation & 14.6 & 15.8 & 14.9 & 12.7 & 8.2 & 6.7 & 5.9 & 8.6 \\
\hline Effective tariffs & 1988 & 1989 & 1990 & 1991 & 1992 & 1993 & 1994 & 1995 \\
\hline Simple average & 52.1 & 46.5 & 47.7 & 34.8 & 20.3 & 16.7 & 13.6 & 20.1 \\
Weighted average* & 46.8 & 38.8 & 37.0 & 28.6 & 17.7 & 15.2 & 12.3 & 15.6 \\
Standard deviation & 36.6 & 44.5 & 60.6 & 36.5 & 17.2 & 13.5 & 8.4 & 37.2 \\
\hline
\end{tabular}

$\left(^{*}\right)$ Weighted by value added.

Table 1: Nominal and effective tariffs, 1988-1995

Figure 7 shows that tariffs seem to have declined slightly more in the more skill-intensive sectors, although not dramatically so, a pattern that will be further investigated below. This contrasts sharply with what was observed in Mexico. Hanson and Harrison (1999) and Robertson (2001), for example, show that Mexican tariffs were relatively lower in skill-intensive sectors before trade liberalization, and decreased less in those sectors.

\section{Empirical Results}

\subsection{Within and Between Industry Decomposition}

Our empirical exercise begins by investigating whether trade liberalization is the main reason for the drop in skill earnings differentials observed in Brazil or whether the increase in skilled labor supply alone can explain it. As discussed below, these two possible explanations have different implications for the results of standard decompositions of skilled-labor relative employment and wage bill shares into within and between industry change (see Berman, Bound and Griliches, 1994 and Autor, Katz and Krueger, 1998).

Changes in skilled-labor employment share $\left(\Delta\left(\frac{L^{S}}{L^{U}+L^{S}}\right)\right)$ may be decomposed in two parts:

$$
\Delta\left(\frac{L^{S}}{L^{U}+L^{S}}\right)=\sum_{j} s_{j} \Delta\left(\frac{L^{S}}{L^{L^{S}}+L^{S}}\right)_{j}+\sum_{j}\left(\frac{L^{S}}{L^{U}+L^{S}}\right)_{j} \Delta s_{j},
$$




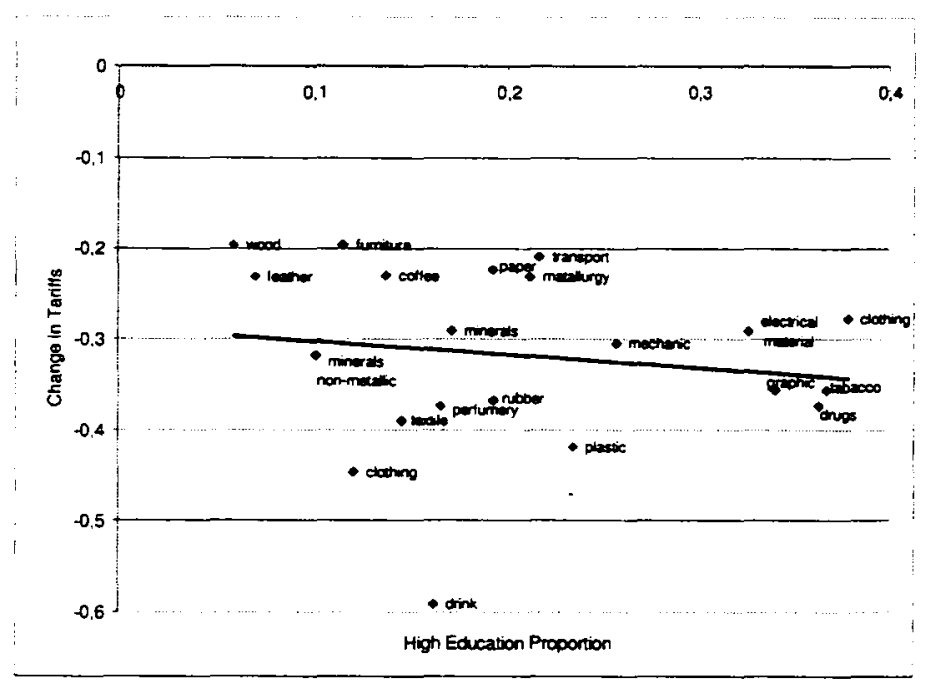

Figure 7: Changes in Tariffs and Skill Proportion

which are interpreted as:

1. within industry changes, which are changes in skilled-labor employment within each industry $\left(\Delta\left(\frac{L^{S}}{L^{U}+L^{S}}\right)_{j}\right)$, for a given employment share in each industry $\left(s_{j}=\frac{\left(L^{U}+L^{S}\right)_{j}}{L^{U}+L^{S}}\right)$;

2. between industry changes, which are changes in each industry employment share $\left(\Delta s_{j}\right)$, for a given skilled-labor employment share in each industry $\left(\left(\frac{L^{s}}{L^{U}+L^{s}}\right)_{j}\right)$.

What would be the results of this decomposition exercise if the increase in relative labor supply were the only significant change in the economy? According to the Rybczynski theorem, for a small open economy, an increase in a factor endowment raises the output of sectors that use that factor intensively, and decreases other sectors' output, without changing the factor proportion used in each industry. In terms of equation 3 , an increase in skilled-labor supply is 
represented by a positive left hand side. Since factor proportions do not change in each industry, the first term on the right hand side, which represents the within industry effect, should be zero. The whole effect should lie in the second term - the between industry effect- which should be positive.

What would be the results of this exercise if trade were the only source behind the changes in wage inequality? As described in Section 3, trade should have caused a decrease in relative prices of skill-intensive sectors in order to produce the observed decrease in wage inequality. On the one hand, these price incentives would decrease production in those sectors, which denote a negative between industry effect. On the other hand, the relative wage incentives would shift labor demand towards skilled workers within each industry, that is, a positive within industry effect. With given factor supplies, the two effects should offset each other. It is important to note, however, that skill biased technological change would also cause a positive within industry effect. The two effects would reinforce each other here, as opposed to the case in developed countries.

Table 2 presents the decomposition results for skilled-labor employment and wage bill shares, using education attainment as a measure of skill. Confirming the labor supply movements displayed in Figure 5, skilled-labor employment share increased $2.67 \%$ a year between 1988 and 1995, on average. The decomposition reveals that the within effect is positive and the between effect is negative. Two important conclusions emerge: (1) labor supply changes alone cannot account for these results, and (2) the results are compatible with the trade explanation. ${ }^{5}$

Table 2 also shows that the wage bill share of skilled workers increased over

\footnotetext{
${ }^{5}$ Results not reported here. using non-production share as a proxy for skill. are also compatible with trade. But in this case. they explain the increase in earnings differentals observed for that skill measure. There was an average overall annual decrease of $0.7 \%$ in non-production cmployment share. This was decomposed into a negative within industry effect $(-1.4 \%)$. which outweighted a positive between industry effect $(0.7 \%)$.
} 


\begin{tabular}{cccc}
\hline & Total & Within Sectors & Between Sectors \\
\cline { 2 - 4 } High Education & 0.0267 & 0.0334 & -0.0067 \\
Employment Share & $(100 \%)$ & $(125 \%)$ & $(-25 \%)$ \\
& & & \\
High Education & 0.0084 & 0.0256 & -0.0172 \\
Wage Bill Share & $(100 \%)$ & $(304 \%)$ & $(-204 \%)$ \\
\hline
\end{tabular}

Table 2: Employment and Wage Bill Shares Decompositions, 1988-95

the period. However, it increased on average less than the employment share, $0.84 \%$ by year. This is compatible with the observed decrease in skilled labor relative wages. Consequently, the skilled worker wage bill share between sector effect is larger compared to that of employment share. The employment share decomposition presents a negative between effect, which means that, on average, cmployment share decreased in industries that use skilled labor more intensively. As these sectors use more of the factor that had its remuneration decreased, it is logical that their overall wage bill share should decrease by a larger proportion than the employment share.

\subsection{Consistency Checks}

In this sub-section, consistency checks examine the causality path predicted by trade theory. As discussed in Section 3, the following relationships should be investigated to determine whether trade liberalization was responsible for the decrease in skilled labor relative earnings observed in Brazil:

1. What was the pattern of relative price changes? To be consistent with the decrease in earnings inequality, one should observe a decrease in the relative prices of the sectors that use skilled labor intensively. This should be reflected in the data through a negative correlation between price changes and skill intensity.

2. Was the pattern of price changes caused by tariff changes? This can be examined through the estimation of price equations based on the rela- 
tionship established in equation (1). If the changes in relative prices in skill-intensive sectors were induced by trade liberalization, one should either observe that the largest tariff reductions occurred in the most skillintensive sectors or that the effect of tariffs on prices was larger in these sectors.

\subsubsection{Prices, Tariffs and Skill Intensity}

The first step is to check whether the pattern of price changes is consistent with the observed decrease in skilled labor relative wages. We start by estimating the following equation:

$$
\Delta \log P_{i \tau}=\beta_{0}+\beta_{1} \log \left(\frac{L^{S}}{L^{U}+L^{S}}\right)_{i, \tau-1}+\nu_{i \tau},
$$

where $P_{i \tau}$ is the wholesale price for sector $i$ in year $\tau$. The pattern of price changes must deliver a negative value for $\beta_{1}$, in order to be consistent with the decrease in skilled-labor relative earnings. Before turning to the estimated equations, Figure 8 shows that. between 1988 and 1995, prices rose less in sectors with a higher proportion of educated workers.

Equation (4) is estimated using a panel of yearly observations from 1988 to 1995 , for a sample of 60 sectors, defined according to the Brazilian Industrial Surveys (PIA). The Brazilian wholesale price index (Índice de Preços por Atacado. IPA) was collected by the Getulio Vargas Foundation and was made compatible with the PIA sectorial definitions. We correct the standard errors of all coefficients here and in the following sub-section for the fact that our independent variable (share of educated workers) is more aggregated than the dependent variables we use.

The results of estimating equation (4), with annual data and controlling for time effects, are presented in the first three columns of Table 3. A signifcant negative correlation between prices and lagged skill intensity was observed: 


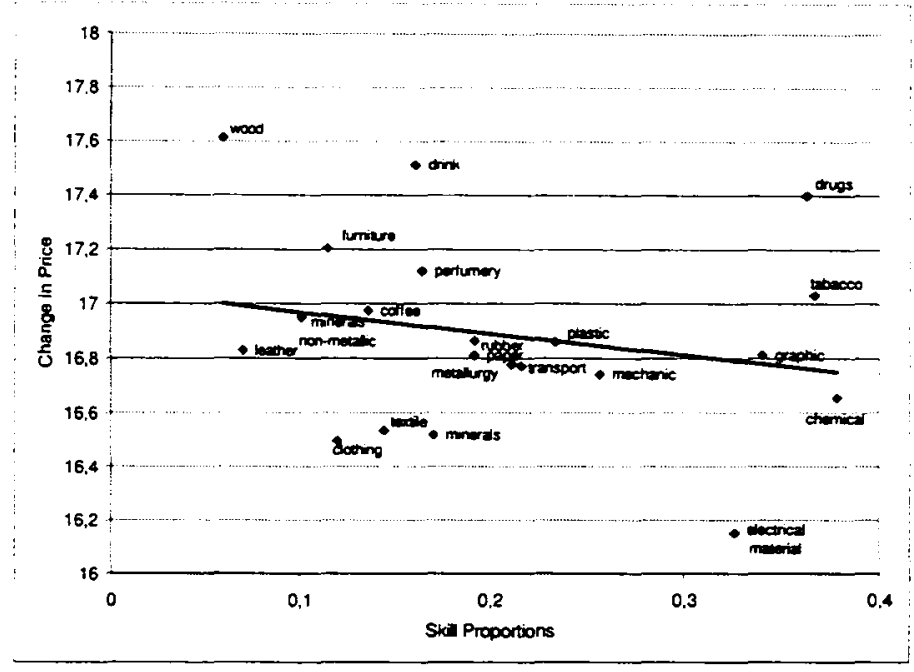

Figure 8: Price Changes and Skill Proportion

showing that rclative prices changed in favor of less skill-intensive sectors. In the second column, we include the sharc of non-production workers as an additional control, which attracts a negative coefficient and significantly raises the estimated education share coefficient. This suggests that the two skill measures are positively correlated with each other, but relative prices moved in opposite directions with respect to them. so that the exclusion of one measure biases the coefficient of the other. In the third column, we do not use the employment weights. with no observed qualitative change in the results. Therefore, relative price changes are consistent with the observed change in earnings differentials.

According to our story, the Heckscher-Ohlin trade transmission mechanism is triggered by a reduction in trade barriers that have different impact across sectors. This could be the result of either a sharper reduction in tariffs in more skill-intensive sectors or a larger impact on prices of the tariffs reduction in these sectors. We investigate the first possibility here, while the second is examined 
in the next sub-section.

We estimate the correlation between tariff changes and skill intensity using the following equation:

$$
\Delta \log (1+t)_{i \tau}=\gamma_{0}+\gamma_{1} \log \left(\frac{L^{S}}{L^{U}+L^{S}}\right)_{i, \tau-1}+\eta_{i \tau}
$$

where $t_{i}$ stands for tariffs in sector $i$, and $\left(\frac{L^{S}}{L^{U}+L^{S}}\right)_{i}$ is the share of skilled labor employed in sector $i$.

The results are presented in columns (3) to (6) in Table 4. Neither skill intensity measures are significantly correlated with the changes in tariffs. Therefore, as suggested by Figure 7, there is no clear pattern of tariff reductions with relation to skill intensity in Brazil.

\begin{tabular}{lccc|ccc}
\hline & \multicolumn{5}{c}{ Change in Prices } & \multicolumn{3}{c}{ Change in Tariffs } \\
\cline { 2 - 7 } & $(1)$ & $(2)$ & $(3)$ & $(4)$ & $(5)$ & $(6)$ \\
Education & -0.043 & -0.070 & -0.053 & -0.002 & -0.001 & -0.001 \\
Employment Share & $(0.020)$ & $(0.019)$ & $(0.021)$ & $(0.004)$ & $(0.004)$ & $(0.005)$ \\
& & & & & & \\
Non-production & - & 0.058 & 0.040 & - & -0.001 & 0.002 \\
Employment Share & & $(0.023)$ & $(0.018)$ & & $(0.006)$ & $(0.006)$ \\
& & & & & & \\
Constant & 3.489 & 3.520 & 0.623 & -0.026 & -0.027 & 0.012 \\
& $(0.039)$ & $(0.038)$ & $(0.035)$ & $(0.013)$ & $(0.013)$ & $(0.006)$ \\
$N$ & 420 & 420 & 420 & 420 & 420 & 420 \\
Time Dummies & yes & yes & yes & yes & yes & yes \\
Weighted Regression & yes & yes & no & yes & yes & no \\
\hline Notes: Weights are the sector employment shares. Robust standard errors are in parentheses
\end{tabular}

Table 3: Tariffs and Skill Intensity, 1988-95

\subsubsection{Prices and tariffs}

From equation (1), domestic prices changes are related to changes in trade barriers and international prices as follows: 


$$
\Delta \log P_{i \tau}=\alpha_{i} \Delta \log \left(1+t_{i \tau}\right)+\Delta \log E+\Delta \log P_{i \tau}^{*} .
$$

Since the nominal exchange rate is the same for every sector, and data on rents generated by other trade barriers is unavailable, the equation to be estimated takes the following form:

$$
\Delta \log P_{i \tau}=\delta_{0}+\delta_{1} \alpha_{i} \Delta \log \left(1+T_{i \tau}\right)+\delta_{2} \Delta \log P_{i \tau}^{*}+\varepsilon_{i}
$$

where $T_{i}$ is the import tariff for sector $i$, and U.S. prices are used as a proxy for international prices $P_{i}^{*}$. Changes in the nominal exchange rate are a component of the constant term, $\delta_{0}$; whereas changes in the rents generated by other trade barriers are captured by the error term, $\varepsilon_{i}$. The expected values for parameters $\delta_{1}$ and $\delta_{2}$ are 1 . Remember that $\alpha_{i}$ is the pass-through coefficient from tariffs to prices in sector $i$. We start by imposing that the pass-through coefficient be equal in all sectors $\left(\alpha_{i}=\alpha, \forall i\right)$, that is, we estimate the coefficient $\delta_{1} \alpha$.

Equation (7) is estimated using a panel of yearly observations from 1988 to 1995 , for the same sample of 60 sectors. U.S. producer price data were drawn from the Bureau of Labor Statistics Website. We could only match 50 U.S. sectors to the equivalent Brazilian sectors.

The first column of Table 4 presents the estimation results when changes in tariffs and in U.S. prices are used as explanatory variables for price changes in Brazil. The estimated tariff coefficient is positive and significantly different from zero at conventional statistical levels. However, the coefficient for U.S. prices is not precisely estimated. This might indicate that U.S. prices are a poor proxy for international prices. Therefore, in column (2) we drop U.S. prices to gain efficiency, but the results do not change qualitatively. Finally, in the third column we use an unweighted regression and show that the results are robust to the use of weights. These results confirm that sectorial prices and tariffs moved 
together for the period as a whole.

\begin{tabular}{lccc}
\hline \multicolumn{4}{c}{ Dependent Variable: Change in Prices } \\
\hline \multirow{3}{*}{ Change in Tariffs } & $(1)$ & $(2)$ & $(3)$ \\
& 0.457 & 0.478 & 0.415 \\
& $(0.237)$ & $(0.233)$ & $(0.218)$ \\
Change in US Prices & 0.105 & - & - \\
& $(0.182)$ & & \\
Constant & & & \\
& 2.882 & 2.315 & 0.646 \\
$N$ & $(0.018)$ & $(0.023)$ & $(0.015)$ \\
Time Dummies & 350 & 420 & 420 \\
Weighted Regression & yes & yes & yes \\
Notes: Robust standard errors are in parentheses. \\
Weights are the sector employment shares.
\end{tabular}

Table 4: Prices and Tariffs, 1988-95

There is one caveat in interpreting the results of this regression. Equation (1) refers to goods prices, and in the empirical estimation we use sectorial prices. The composition of goods within each sector may change over time, and this change may be correlated with changes in trade policy. On the one hand, trade liberalization may reduce or even eliminate domestic production of goods with relatively high domestic production costs. On the other hand, new products may be introduced due to the reduced cost of imported goods. Even though this is a drawback, there is nothing we can do to correct for possible measurement errors caused by it.

We now allow for a different pass-through coefficient across sectors. As discussed above. although tariff changes and skill intensity showed no significant correlation, it is still possible that relative price changes. which were consistent with the relative wages changes, were caused by trade. This would be true if sectors have different tariff pass-through coefficients, in such a way that the tariff 


\begin{tabular}{|c|c|c|c|}
\hline \multicolumn{4}{|c|}{ Dependent Variable: Change in Prices } \\
\hline & (1) & (2) & (3) \\
\hline Change in tariffs * & 0.393 & 0.402 & 0.164 \\
\hline Low Education Share Indicator & $(0.271)$ & $(0.269)$ & $(0.261)$ \\
\hline Change in tariffs ${ }^{*}$ & 0.591 & 0.635 & 0.783 \\
\hline High Education Share Indicator & $(0.311)$ & $(0.303)$ & $(0.265)$ \\
\hline Change in US prices & $\begin{array}{c}0.115 \\
(0.184)\end{array}$ & - & - \\
\hline Constant & $\begin{array}{c}2.882 \\
(0.018)\end{array}$ & $\begin{array}{c}2.315 \\
(0.024)\end{array}$ & $\begin{array}{c}0.646 \\
(0.015)\end{array}$ \\
\hline $\mathrm{N}$ & 350 & 420 & 420 \\
\hline Time Dummies & yes & yes & yes \\
\hline Weighted Regression & yes & yes & no \\
\hline
\end{tabular}

Table 5: Prices and Tariffs by Skill Intensity, 1988-95

where $\theta_{j}^{S}$ is the cost of skilled labor and $\theta_{j}$ is the total cost in sector $\mathrm{j}$. Therefore, regressing price changes on skilled labor cost share should yield an estimate of the economy-wide returns to skill changes.

Our estimation is based on the following regression:

$$
\Delta \log p_{j}=\phi_{0}+\phi_{1}\left(\frac{w^{S} L^{S}}{w^{U} L^{U}+w^{S} L^{S}}\right)_{j}+\eta_{j},
$$

where the estimated coefficient $\phi_{1}$ is interpreted as the changes in skill earnings differentials associated with price changes. ${ }^{6}$

Since we are interested in the effect of prices that resulted from trade liber-

${ }^{6}$ The general form for equation $(8)$ when there are $l$ factors of production is:

$$
\Delta \log p_{j}=\frac{\theta_{j}^{1}}{\theta_{j}}\left(\Delta \log w^{1}-\Delta \log w^{2}\right)+\frac{\theta_{j}^{1}+\theta_{j}^{2}}{\theta_{j}} \Delta \log w^{2}+\sum_{k=3}^{l}\left(\frac{\theta_{j}^{k}}{\theta_{j}} \Delta \log w^{k}\right) .
$$

In this case, one could still use equation (9), but the coefficient $\phi_{1}$ should equal $\frac{\theta_{j}^{S}+\theta_{j}^{L}}{\theta_{j}}\left(\Delta \log w^{S}-\Delta \log w^{U}\right)$, which would be well estimated if the share of labor in total cost is time invariant. An analogous argument applies for the constant term in equation (9). 
alization, we follow Haskel and Slaughter (2002) and estimate the equation (9) in two steps. First, we estimate the change in prices predicted by the change in tariffs. For this step, we compute two alternative sets of predicted prices: those that result from the estimation of equation (7), presented in Table 4, and those that result from allowing different pass-through coefficients according to sector skill intensity, presented in Table 5. In the second step, we estimate equation (9) using the predicted prices, instead of actual prices, as the dependent variable. In this case, the estimated coefficient $\phi_{1}$ is interpreted as the changes in returns to skill that are mandated by price changes induced by trade liberalization.

\begin{tabular}{lcc}
\hline & \multicolumn{3}{c}{ Dependent Variable: Change in Prices } \\
\hline & $\begin{array}{c}\text { Predicted } \\
\text { by tariffs }\end{array}$ & $\begin{array}{c}\text { Predicted by tariffs, } \\
\text { diff. pass-through }\end{array}$ \\
\hline Education Cost Share & $(2)$ & $(3)$ \\
& -0.007 & -0.029 \\
& $(0.006)$ & $(0.006)$ \\
Constant & 2.300 & 2.310 \\
& $(0.003)$ & $(0.003)$ \\
& & \\
\hline Auxiliary Regression & Table $3(2)$ & Tablc $4(3)$ \\
Actual Change in Wage Diffs & -0.024 & -0.024 \\
$N$ & 420 & 420 \\
Time Dummies & yes & yes \\
\hline
\end{tabular}

Notes: Weights used in the first three columns are the sector employment shares. Robust standard errors are in parentheses.

Table 6: Mandated Wages

The results are presented in Table 6 . The actual annualized fall in skill earnings differentials observed in Brazil was $2.4 \%$ on average. The first column shows that the decline in earnings differentials mandated by the price variation predicted by the change in tariffs was estimated at $0.7 \%$, but was not significantly different from zero. However, when we use the price changes predicted by tariffs, allowing for different pass-through coefficients (column 2), we find a mandated anmualized skill carnings differential decline of $2.9 \%$. which is very 
coefficient, which implies that relative prices indeed fell in skill intensive sectors. Although tariff changes across sectors were not related to skill intensities, we find that the pass-through from tariffs to prices was stronger in skill intensive sectors. This is consistent with trade liberalization being responsible for the relative fall in prices of skill intensive sectors.

Finally, we apply a mandated wage equation analysis. We show that the decline in skilled earnings differentials mandated by the price variation predicted by trade is very close to the observed one. The predicted price variation was obtained by regressing price changes on tariff changes, allowing for different pass-through coefficients.

In sum, all steps of the trade transmission mechanism were tested, and the results are compatible with trade liberalization accounting for the observed relative earnings changes in Brazil.

The results described above are obtained when we use education attainment as a proxy for skill. Most of the literature for developing countries uses the share of non-production workers instead. We show that one obtains opposite results when this alternative measure is used for Brazil: non-production workers relative earnings increased over the period. We also present some results which are consistent with the trade transmission mechanism explaining the increased differential for this other measure. This should be taken as a warning for studies on countries that do not have an education attainment measure, and have to use the non-production measure as a proxy for skill.

An issue that requires further investigation is the reason behind different pass-through coefficients from tariffs to prices. We found that the impact of tariffs on prices was stronger in skill intensive sectors. We argue that this could be due to Brazil having a comparative advantage in producing goods that use unskilled workers intensively, which would imply that the change in tariffs in these sectors would have no important effect on prices. 


\section{References}

[1] Autor, David, Lawrence Katz and Alan Krueger (1998). "Computing Inequality: Have Computers Changed the Labor Market?," The Quarterly Journal of Economics, 113(4): 1169-1213, November.

[2] Baldwin, Robert and Glen Cain (1997). "Shifts in U.S. Relative Wages: The Role of Trade, Technology and Factor Endowments", NBER Working Paper \#5934.

[3] Barros, Ricardo Paes de, Ricardo Henriques and Rosane Mendonça (2000), "Education and Equitable Economic Development", Economia, 1: 111-144.

[4] Beyer, H., Rojas, P. and Vergara, R. (1999). "Trade Liberalization and Wage Inequality," Joumal of Development Economics, 59: 103-123.

[5] Berman, Eli, John Bound and Zvi Griliches (1994). "Changes in the Demand for Skilled Labor within US Manufacturing: Evidence from the Annual Survey of Manufacturers:" The Quarterly Journal of Economics, 109(2): 367-398, May.

[6] Berman, Eli, John Bound and Stephen Machin (1998). "Technology and Changes in Skill Structure: Evidence from Seven OECD Countries," The Quarterly Journal of Economics, 113(2): 1215-44.

[7] Harrison, A. and Hanson, G. (1999). "Trade Liberalization and Wage Inequality in Mexico," Industrial and Labor Relations Review, 52(2): 272-288.

[8] Haskel, Jonathan E. and Matthew J. Slaughter (2002) "Have Falling Tariffs and Transportation Costs Raised U.S. Wage Inequality?," Review of International Economics, forthcoming. 
[9] Johnson, G. and F. Stafford (1999). "The Labor Market Implications of International Trade," in O. Ashenfelter and D. Card (eds.), Handbook of Labor Economics, vol. 3, 2215-2288.

[10] Kume, Honório (2002). "A política brasileira de importação no periodo 1987-99: descrição e avaliação," May, mimeo.

[11] Lam, D. and Shoeni, R.(1989). "The Effect of Family Background on Earnings and Returns to Schooling: Evidence from Brazil ", Journal of Political Economy, 101: 711-38.

[12] Lam, D. and Levinson, D. (1992). "Declining Inequality in Schooling in Brazil and its Effect on the Inequality of Earnings", Journal of Developing Economics. 137: 199-225.

[13] Katz, L. and Autor, D. "Changes in Wage Structure and Earnings Inequality" in O. Ashenfelter and D. Card (eds.), Handbook of Labor Economics, vol. 3, 2215-2288, 1999

[14] Krueger, Alan (1997). "Labor Market Shifts and The Price Puzzle Revisited", NBER Working Paper \#5924.

[15] Lawrence, Robert and Matthew Slaughter (1993). "International Trade and American Wages in the 1980s: Giant Sucking Sound or Small Hiccup," Brooking Papers on Economic Activity, 2:161-226.

[16] Leamer, Edward (1996). "In Search of the Stolper-Samuelson Effects on US Wages," NBER Working Paper \# 5427.

[17] Robertson, Raymond (2001). "Relative Prices and Wage Inequality: Evidence from Mexico", Macalester College, mimeo. 
[18] Slaughter, Matthew (1998). "What are the Results of Product-Prices Studies and What Can We Learn from Their Differences?," NBER Working Paper \#6591.

[19] Squire, H. and Zou, H-F. (1998), "Inter-National and Intra-National Inequality", The Economic Journal, 108:26-45.

[20] United Nations Development Program (2000), Human Development Report. 
+ :

000312028 

NA ÚLTIMA DATA MARCADA

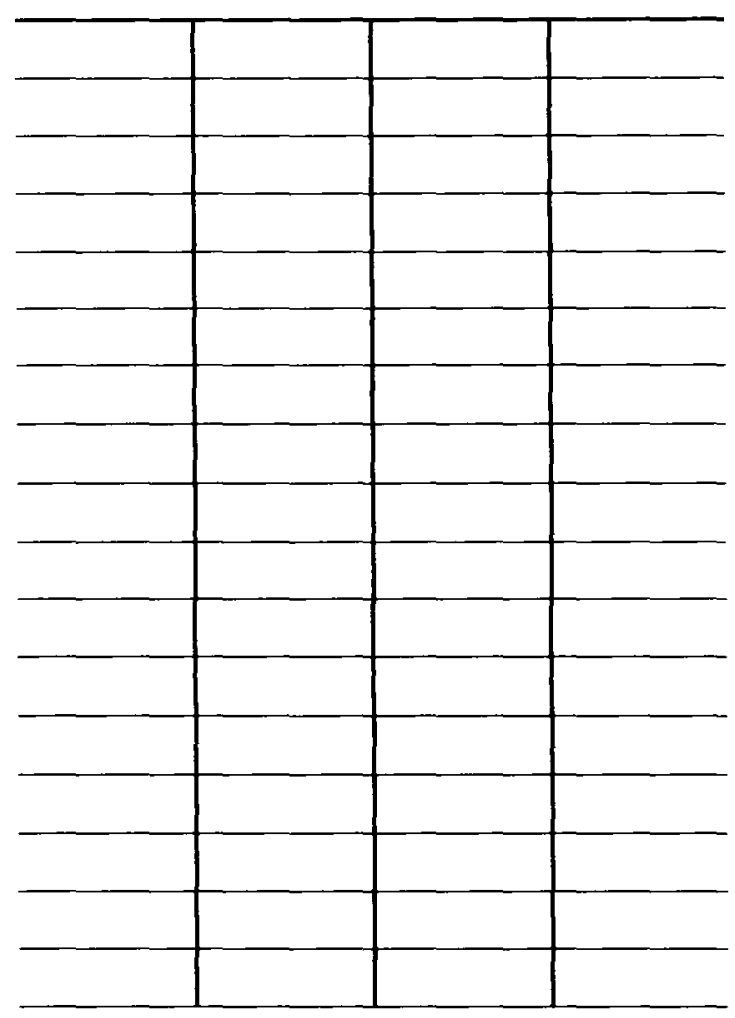

\begin{tabular}{|c|}
\hline 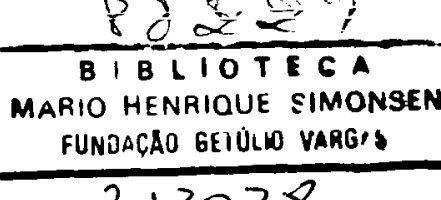 \\
\hline$\frac{312028}{1811112002}$ \\
\hline
\end{tabular}

N.Cham. P/EPGE SPE T323t

Autor: Terra, Maria Cristina T.

Título: Trade liberalization and the evolution of skill earn 